\title{
Working
}

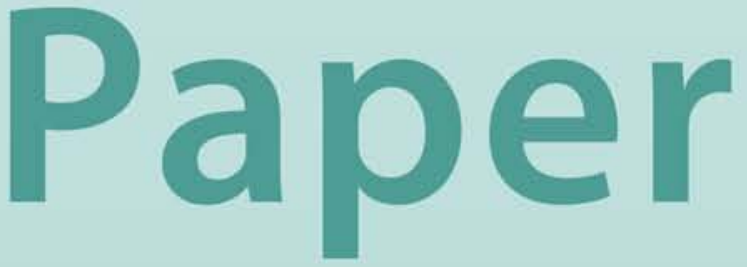




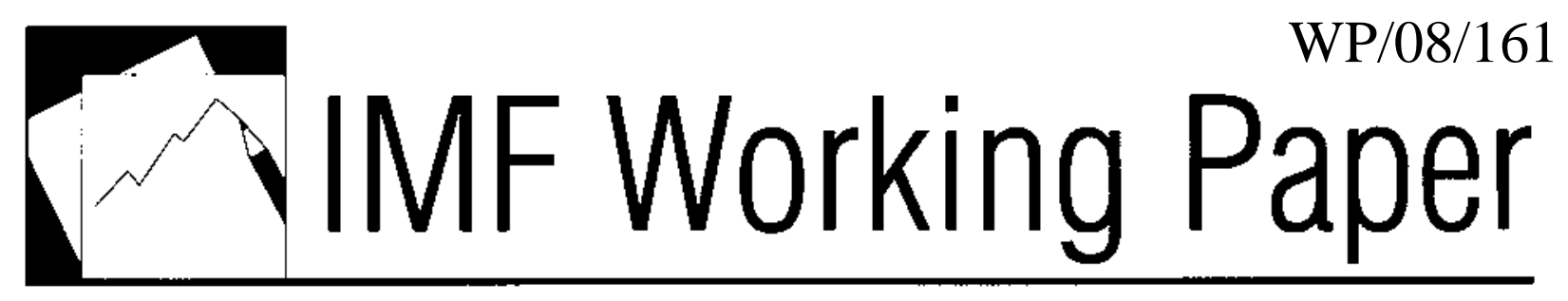

A U.S. Financial Conditions Index:

Putting Credit Where Credit is Due

\author{
Andrew Swiston
}




\title{
IMF Working Paper
}

Western Hemisphere Department

\section{A U.S. Financial Conditions Index: Putting Credit Where Credit is Due}

\author{
Prepared by Andrew Swiston ${ }^{1}$
}

Authorized for distribution by Tamim Bayoumi

June 2008

\begin{abstract}
This Working Paper should not be reported as representing the views of the IMF. The views expressed in this Working Paper are those of the author(s) and do not necessarily represent those of the IMF or IMF policy. Working Papers describe research in progress by the author(s) and are published to elicit comments and to further debate.

This paper uses vector autoregressions and impulse-response functions to construct a U.S. financial conditions index (FCI). Credit availability_proxied by survey results on lending standards - is an important driver of the business cycle, accounting for over 20 percent of the typical contribution of financial factors to growth. A net tightening in lending standards of 20 percentage points reduces economic activity by $3 / 4$ percent after one year and $1 \frac{1}{4}$ percent after two years. Much of the impact of monetary policy on the economy also works through its effects on credit supply, which is evidence supporting the existence of a credit channel of monetary policy. Shocks to corporate bond yields, equity prices, and real exchange rates also contribute to fluctuations in the FCI. This FCI is an accurate predictor of real GDP growth, anticipating turning points in activity with a lead time of six to nine months.

15B

JEL Classification Numbers: E32, E44, E47, E51
\end{abstract}

Keywords: Financial conditions index, vector autoregression, credit channel, macro-financial linkages

Author’s E-Mail Address: aswiston@imf.org

\footnotetext{
${ }^{1}$ Thanks to Tamim Bayoumi, Koshy Mathai, Ola Melander, seminar participants at the International Monetary Fund, and participants in a seminar for U.S. officials for their comments and suggestions. All errors remain the author's.
} 
I. Introduction and Literature Review

II. Building a Better Financial Conditions Index ............................................................ $\underline{6}$

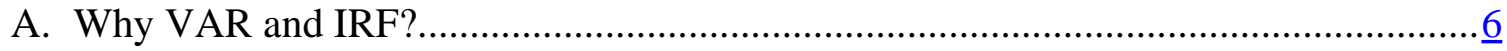

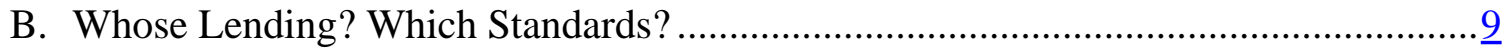

C. Which Other Variables Enter the Mix? ................................................................. 12

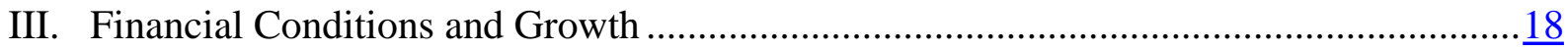

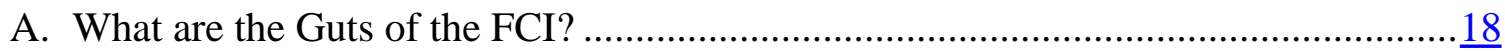

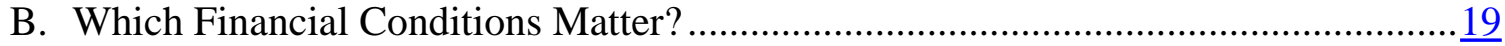

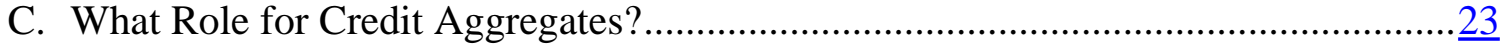

D. What is the FCI's Contribution to Growth? .......................................................... 25

E. Where Do Financial Conditions Hit Hardest? ....................................................

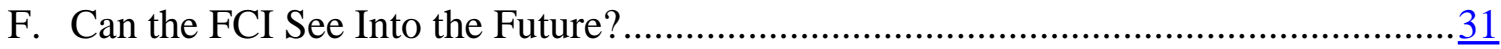

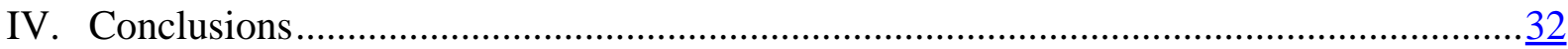

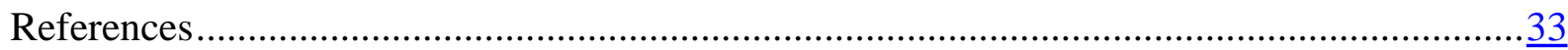

Tables

1. Lending Standards and Real Activity: Correlations ...............................................10

2. Lending Standards and Financial Variables: Correlations........................................ 10

3. Financial Conditions and Real Activity: Correlations and Variance Decompositions...... $\underline{26}$

Figures

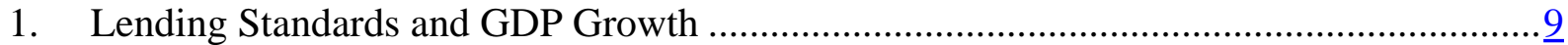

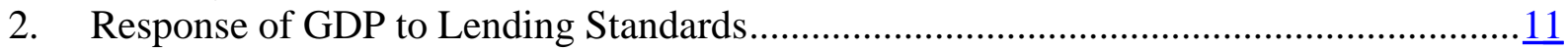

3. Response of GDP to Risk-Free Interest Rates ....................................................... $\frac{14}{15}$

4. Response of GDP to Default Risk and Volatility …..............................................15

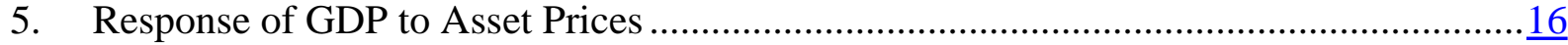

6. Lending Standards and the High Yield Spread........................................................ $\frac{17}{21}$

7. Response of GDP to Financial Shocks ............................................................. $\frac{21}{22}$

8. Response of Financial Conditions to Lending Standards ...........................................22

9. Credit Availability and the Impact of Monetary Policy on Growth ................................23

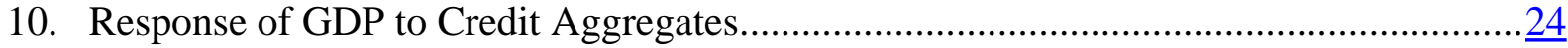

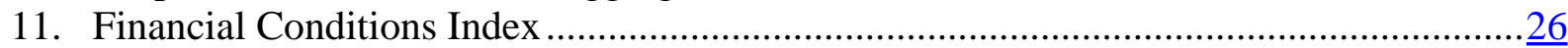

12. Financial Shocks and Contributions to the FCI ................................................... $\frac{28}{29}$

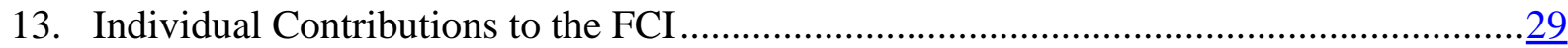

14. Response of Components of Demand to Financial Shocks …...................................... 30

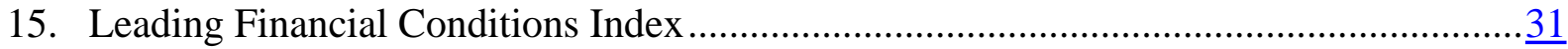




\section{INTRODUCTION AND LITERATURE REVIEW}

This paper constructs a measure of economy-wide financial conditions for the United States. The goal is to provide a reasonably comprehensive, yet tractable model within which to analyze the impact on real economic activity of high-frequency movements in financial markets.

Interest in the effects of monetary policy on the economy is hardly new, as the seminal work of Friedman and Schwartz (1963) spawned an entire field devoted to identifying monetary policy shocks and estimating their effects on the economy. ${ }^{2}$ However, the rapidly growing complexity of financial systems of countries like the United States necessitates a broader view, for two reasons. First, sound estimates of the impact of other financial markets on the real economy are required, because of their possible importance in aggregate economic fluctuations. Second, if movements in other financial variables that affect the economy are correlated with monetary policy yet no account is taken of their impact, estimates of the role played by monetary policy in determining activity and prices could be biased.

Analysis of the effects on growth and inflation of financial conditions more broadly has taken a number of approaches. Gauthier et al (2004), Batini and Turnbull (2002), Goodhart and Hofmann (2001, 2002), and Mayes and Virén (2001) built Financial Conditions Indices (FCIs) using coefficients based on estimated IS curves. Gauthier et al (2004) also calculate an FCI using a vector autoregression (VAR). Macroeconomic Advisers (1998) and Dudley and Hatzius (2000) employ FCIs based on large-scale macroeconometric models. English et al (2005) build factor models for the United States, United Kingdom, and Germany that each incorporate three to four dozen financial variables, and use the factors, including lagged values, to predict the output gap and inflation. Stock and Watson (2003) forecast output growth using the trimmed mean of a number of univariate output forecasts, and find that this method improves accuracy relative to simple univariate methods.

Most of this work has focused on the signals sent by prices of financial assets, without distinguishing between the effects of credit demand versus supply on these prices, or looking at other ways to measure the economic impact of shifts in credit supply. ${ }^{3}$ A rise in corporate spreads provoked, for example, by increased demand for borrowing to finance productive investment may indicate that economic activity will expand. However, the same rise in spreads, if caused by the reduced willingness of lenders to extend credit on previous terms due to a lack of availability of funds, could signal a future slowdown.

\footnotetext{
${ }^{2}$ Romer and Romer (1989), Boschen and Mills (1991), Strongin (1995), and Bernanke and Mihov (1998) develop indicators of monetary policy conditions. Bernanke and Blinder (1992), Sims (1992), Christiano et al (1996), and Bernanke et al (2005) are among those exploring the effects of monetary policy on the economy.

${ }^{3}$ English et al (2005) consider variables that could isolate the effects of credit supply and demand, but they do not attempt to identify a specific credit supply factor within their model.
} 
This distinction between shifts in demand and supply becomes especially important in a world of uncertainty and asymmetric information. Financial institutions may engage in credit rationing to limit their exposure to moral hazard (Stiglitz and Weiss, 1981). This implies that shifts in the supply of funds available from financial institutions may manifest themselves as movements in the quantity of credit rather than changes in the price.

Examining movements in the quantity of credit extended along with price changes could help to evaluate whether shifts in credit demand or supply predominate in a given period, but their information content is diminished by the fact that most credit aggregates cover only external finance. The procyclicality of firm cash flows-and access to internal funds to finance investment - means that the quantity of credit extended may not show the expected procyclical pattern. Rather, as the economy slows and profits dry up, if rising demand for external finance is driving credit growth, the behavior of credit aggregates would be sending the wrong message about the future direction of the economy. A similar argument could be made for cyclical movements in households' discretionary income and consumer credit, although these would be expected to show less sensitivity to the business cycle.

This paper therefore focuses on the concept of "credit availability"-the willingness of lenders to provide funds at the market interest rate. This willingness can fluctuate because of credit market imperfections. Some examples of ways that credit availability could vary include non-interest fees, the maturity of credit extended, maximum credit size, loan covenants, credit score requirements, and collateralization requirements. The advantage of analyzing credit availability is that it is closely related to credit supply, and can be seen as relatively independent of factors underlying credit demand. To the extent credit availability can be measured, it can usefully complement data on prices and quantities in discerning whether overall financial conditions are accommodative or restrictive.

Examination of the role of credit availability in aggregate economic fluctuations has been particularly active in relation to the credit channel of monetary policy transmission. Bernanke and Blinder (1988) developed a model in which a tightening of monetary policy reduced output by draining reserves from the banking system and thus restricting the quantity of credit that banks are able to supply — the bank lending channel. ${ }^{4}$ Bernanke and Blinder (1992), and Kashyap and Stein (2000) provide evidence confirming this channel's existence-in the first case showing the aggregate decline in bank lending in response to contractionary monetary policy shocks, and in the second finding that banks with less liquid balance sheets cut back on lending more when monetary policy tightens. ${ }^{5}$

\footnotetext{
${ }^{4}$ Bernanke et al (1999) present a model showing more generally how credit market imperfections can propagate shocks.

5 There is also some literature on a closely-related bank capital channel of monetary policy transmission. See, e.g. Greenlaw et al (2008), Gambacorta and Mistrulli (2004), and Van den Heuvel (2002). The impact of either channel relies critically on the idea that banks face an upward-sloping supply curve for raising funds.
} 
Monetary policy shocks also impact credit supply through their effects on the cash flow and collateral asset values of firms and households. A monetary policy contraction worsens borrower balance sheets, which reduces the willingness of financial institutions to lend at the going interest rate and increases the external finance premium - the balance sheet channel. Gertler and Gilchrist (1994) show that the effects of monetary policy are greater for small manufacturing firms than large ones, supporting the existence of the balance sheet channel in that financial frictions are likely to be especially important for small firms. Ashcraft and Campello (2007) find that small subsidiary banks within the same bank holding company cut back lending more in geographical areas that have been hit harder by a monetary policy shock, suggesting that considerations related to borrower balance sheets play a role.

One common thread in most analysis of the credit channel is the focus on monetary policy and credit quantities. Simultaneously considering other financial variables that are important in determining both economic activity and the quantity of credit may lead to more precise estimates of the response of output to credit availability.

This paper brings together an emphasis on broad financial conditions with a concern for capturing the role of credit availability in the business cycle. The FCI constructed in this paper contains three features that, when combined, more accurately measure the true response of economic activity to financial conditions, namely:

- $\quad$ The FCI includes a broad range of variables (and examines, but rejects, still others) covering major financial markets and channels of transmission to the real economy. The inclusion of a measure of credit availability - from the Federal Reserve's Senior Loan Officer’s Opinion Survey on Lending Standards-along with asset price variables, is of particular importance.

- Estimation is conducted in a VAR framework. Unlike the IS-curve analysis common in the literature, estimates of the linkages between financial markets and the real economy incorporate the endogenous response of financial variables to economic activity, as well as to each other. Accounting for these effects is important when attempting to disentangle the impact of multiple variables that are highly correlated.

- The FCI is calculated with a dynamic weight structure computed using impulseresponse functions (IRFs) from a VAR, allowing the FCI to accurately incorporate the timing of transmission from financial markets to real activity.

The FCI calculated here contains statistically significant effects on GDP growth from shocks to lending standards, corporate bond yields, equity prices, and real exchange rates, while credit quantities contain little information about future economic activity that is not captured by lending standards. This FCI is an accurate predictor of real GDP growth; because it incorporates information from financial shocks over a period of eight quarters preceding the quarter in which GDP is measured, it contains a substantial amount of leading information about economic activity. 
Credit availability, as measured by lending standards, is highly procyclical and an important driver of the business cycle, accounting for over 20 percent of the typical contribution of financial factors to growth. On average, a net tightening in lending standards of 20 percentage points reduces economic activity by $3 / 4$ of a percent after one year and $1 \frac{1}{4}$ percent after two years. As expected, shifts in credit availability affect business and residential investment more than consumption.

For the period under analysis here, the impact of monetary policy is improperly identified when credit availability is not incorporated into the model. In recent decades economic activity only responds to the policy interest rate when accounting for the endogenous response of credit availability to interest rates and growth. This is evidence supporting the existence of a credit channel of monetary policy.

The rest of the paper proceeds as follows: Section II motivates the use of a VAR framework for conducting the analysis; describes the lending standards survey that proxies for credit availability and examines its relationship with financial markets and economic growth; and analyzes the impact on economic activity of several financial variables. Section III describes the FCI; estimates the effects on growth of overall financial conditions and of the individual components; and examines the FCI's properties as a leading indicator of economic activity. Section IV concludes.

\section{Building A Better FinANCiAL Conditions IndeX}

\section{A. Why VAR and IRF?}

This section justifies the use of VARs and impulse response functions (IRFs) in constructing an FCI. Criticism of the analysis of the effects of financial shocks has raised several valid issues (see, e.g. Eika et al, 1996). The focus here will be on the dynamic impact of financial conditions on growth and on the non-exogeneity of regressors, which also encompasses the problem of the identification of shocks. Other issues raised include model dependence, parameter inconstancy, omitted variables, and whether correlation implies causality, all of which affect other methodologies just as much as VARs. ${ }^{6}$

An FCI constructed without dynamic weights may quantify the eventual magnitude of the impact on growth of current developments in financial markets, but neglects the question of the timing over which these effects will occur. A central banker setting monetary policy, itself an instrument which only affects the economy with lags, is only fully informed about the pros and cons of competing options if information of this type is available. Dynamic responses can be calculated using any methodology, but many FCIs neglect this issue. The typical approach is to calculate each variable's weight in the FCI as the sum of its

\footnotetext{
${ }^{6}$ With respect to the issue of causality, the difficulty in capturing macrofinancial linkages in general equilibrium models forces most analysts to look at correlation as a general indication of the effects of financial variables, and that approach is taken in this paper.
} 
contemporaneous and lagged coefficients in the IS curve; or as the relative magnitude of the response of GDP in some future period to a shock to the current value of each variable. Batini and Turnbull (2002), Gauthier et al (2004), and Macroeconomic Advisers (1998) are the only authors to construct FCIs that account for the timing of lagged transmission effects.

The main advantage of a VAR-based FCI with respect to other methodologies is its ability to account for the impact of shocks to financial variables on other variables in the system. Consider an IS curve equation in which economic activity, $y$, is a function of its own lagged values and of $m$ lags of $n$ other price and financial variables:

$y_{t}=\alpha+\sum_{i=1}^{m} \beta_{i} y_{t-i}+\sum_{j=1}^{n}\left[\sum_{i=1}^{m} \varphi_{j, i} x_{j, t-i}\right]+e_{t}$

Where the $x$ 's are the other variables and $e$ is an error term. The coefficients $\varphi$ are generated by estimating the impact of each $x$ on $y$, holding constant the other $x$ 's, implicitly treating all the regressors as exogenous to each other. However, if changes in one independent variable are typically associated with movements in the other independent variables, then the estimated response of output to each individual financial variable could be biased.

In a VAR, all variables in the system are endogenous, so that the impact of, for example, monetary policy on economic activity includes both the direct effect of higher interest rates and indirect effects through the impact of higher interest rates on other financial market variables that affect growth in turn. The estimated model then becomes the system of equations represented by:

$$
X_{t}=\sum_{i=1}^{m} A_{i} X_{t-i}+v_{t}
$$

Where $X$ is a vector of all the variables, $A$ is a vector of coefficients, and $v$ is a vector of error terms. This framework is particularly appropriate when dealing with financial variables, as there are a priori theoretical relationships between them due to considerations like the expectations hypothesis of the term structure and the discounted cash flow approach to asset valuation.

An IRF measures the impact of any variable on the other variables in $X$ by shocking the error term for that variable's equation in (2) and tracing out the effects through all the equations in the system. The issue of dynamic weights in an FCI becomes straightforward using IRFs, as the weight on a particular variable for any time $i$ periods in the future is merely the response of economic activity at time $t+i$ to a shock to the variable at time $t$.

The main challenge in using a VAR framework is in determining the contemporaneous relationships between variables in the system in the presence of shocks to each variable. As shown in the system of equations in (2), a VAR does not produce estimates of the 
contemporaneous relationship between variables in $X$. Thus, in order to estimate IRFs, the v's in system (2) need to be decomposed into the portion due to exogenous disturbances to each variable, and the portion due to the effects on each variable of contemporaneous shocks to the other variables in the system.

This paper orders the variables in the model according to their relative sluggishness-i.e., the degree to which they respond to developments occurring in other variables within the quarter - in order to compute orthogonalized IRFs using standard Cholesky decompositions (see Sims, 1980). The Cholesky decomposition of shocks from, for example, a 3-variable VAR assigns all of the correlation between the errors in the first equation and the second and third ones to the first variable, while any remaining correlation between the errors in the second and third equations is assigned to the second, and etc. for VARs with more variables. This implies that both the magnitude of the shocks and the estimated responses of the variables to each other depend, to some extent, on the assigned ordering. ${ }^{7}$

Within this framework, the estimated response of GDP to each of the financial variables can be combined with the measure of shocks to each variable to calculate the total impulse to growth in a given quarter. GDP is assumed to be relatively more sluggish than the other variables in the system-shocks to financial variables in the current period do not affect GDP because of the primacy of GDP in the Cholesky ordering. The FCI can thus be given by equation (3):

$$
F C I_{t}=\sum_{j=1}^{n}\left[r_{t, j_{t-1}}+\sum_{i=2}^{m}\left(r_{t, j_{t-i}}-r_{t-1, j_{t-i}}\right)\right]
$$

Where $r$ 's are the responses of GDP to each variable in the VAR, the $j$ 's index the variables and the $i$ 's index the time period. The first term inside the brackets represents the response of GDP in quarter $t$ to a financial shock occurring in the previous quarter. Because the variables in the system are expressed in levels, the marginal current impact of a shock that occurred before the previous quarter - the term inside the second summation - is measured by subtracting the shock's effect on the level of GDP in the previous period from its effect on the level of GDP in the current period. The FCI thus measures the total contribution to GDP growth in a given quarter from shocks to financial variables over the previous $m$ quarters.

\footnotetext{
${ }^{7}$ Pesaran and Shin (1998), among others, point out that this results in some element of subjectivity, especially in cases where there is no clear a priori direction of causality in the contemporaneous relationship between two variables. They develop a method of calculating generalized impulse-response functions (GIRFs), which does not depend upon the ordering of the variables. However, its appropriateness can be questioned in systems of equations where some contemporaneous causal relationships can be identified. Results using GIRFs were qualitatively unchanged from those shown here, except that the first period response (under a Cholesky decomposition, constrained to be zero for variables earlier in the ordering) was often of a counterintuitive sign before switching to the correct sign. These anomalous results generate a preference for using Cholesky decompositions to orthogonalize the shocks in this application.
} 


\section{B. Whose Lending? Which Standards?}

This section examines the ability of responses to the Federal Reserve's Senior Loan Officer Opinion Survey on Lending Practices (SLOOS) to proxy economy-wide conditions of credit availability. The following is the wording of the question on commercial and industrial (C\&I) bank loan standards contained in the survey, along with the possible responses:

Over the past three months, how have your bank's credit standards for approving applications for commercial and industrial loans or credit lines-other than those to be used to finance mergers and acquisitions_changed? 1) Tightened considerably. 2) Tightened somewhat. 3) Remained basically unchanged. 4) Eased somewhat. 5) Eased considerably.

Questions containing the same possible responses are asked with regard to loans for commercial real estate (CRE), residential mortgages, and consumer credit. The data are reported in terms of the net percentage of banks tightening standards in a given period, summing the number responding 1 and 2 and subtracting the number responding 4 and $5 .{ }^{8}$

Note that the survey question asks about standards "Over the past three months". The survey is typically conducted in the first month of each quarter and published early the next month. This means that the reported standards pre-date most economic and financial data pertaining to the period in question. Thus, a strong argument can be made for giving lending standards primacy when determining the ordering of multiple financial shocks occurring in the same quarter - a simultaneous rise in corporate spreads and tightening of lending standards can be attributed to the tightening of standards because it happened before the rise in spreads.

The survey responses are highly correlated with both real activity and financial market variables, suggesting that they are indeed a valid proxy for conditions of credit availability. Figure 1 plots the simple average of the four categories of standards against the four-quarter percent change in real GDP. ${ }^{9}$ Periods of sharp tightening in lending standards match up quite closely with the onset of economic downturns, as credit availability was tightened in advance of both the 1990-1991 and

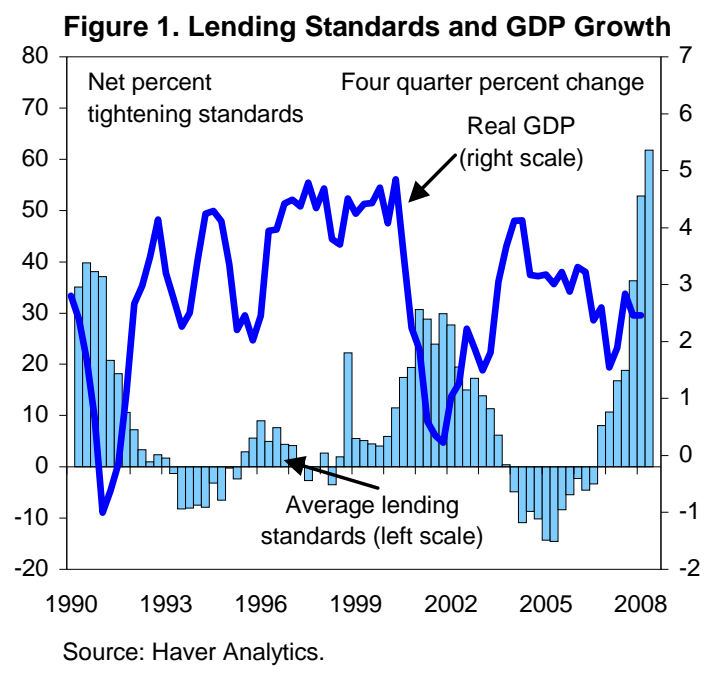

\footnotetext{
${ }^{8}$ See Lown et al (2000) and Lown and Morgan (2006) for further detail on the survey.

${ }^{9}$ The average makes use of all categories available in a particular period. C\&I standards are available from 1990Q2, CRE from 1990Q3, residential mortgages from 1990Q4, and (non-credit card) consumer loans from 1996Q1. The latter category is spliced with the inverse of "willingness" to make consumer installment loans, to extend it back to 1990, as the correlation between the two series since 1996 is -0.79 .
} 
2001 recessions, and the current slowdown. Conversely, periods of ample credit availability, proxied by a net easing of standards or low levels of tightening (there is some apparent bias toward tightening in the responses), are associated with robust GDP growth.

There also exists a strong association between lending standards and future economic activity, as the correlation of C\&I, CRE, and average standards with the quarterly percent change in real GDP remains at between -0.3 and -0.4 two to three quarters into the future (Table 1).

Standards are also generally associated with future cuts
Table 1. Lending Standards and Real Activity: Correlations (sample: 1990Q2-2008Q1)

\begin{tabular}{lrrrrrr}
\hline \multicolumn{1}{c}{ Standards } & \multicolumn{5}{c}{ Real GDP } \\
\cline { 2 - 7 } & $\mathrm{c}$ & $\mathrm{t}+1$ & $\mathrm{t}+2$ & $\mathrm{t}+3$ & $\mathrm{t}+4$ \\
\cline { 2 - 7 } & & -0.46 & -0.46 & -0.39 & -0.31 & -0.16 \\
\hline Commercial and industrial & -0.48 & -0.48 & -0.38 & -0.19 & -0.16 \\
Commercial real estate (1990Q3) & -0.35 & -0.21 & -0.09 & -0.01 & -0.04 \\
Residential mortgage (1990Q4) & -0.25 & -0.11 & -0.05 & 0.09 & 0.20 \\
Consumer credit & -0.49 & -0.46 & -0.38 & -0.22 & -0.11 \\
Average standards & 0.38 & 0.37 & 0.30 & 0.19 & 0.09 \\
Bank capital-asset ratio & & & & &
\end{tabular}

Source: IMF staff calculations.

in short-term interest rates, lower real equity returns, and wider spreads on corporate debt (Table 2). The relationships between lending standards, real activity, and financial variables are exactly what one would expect between a measure of credit availability and these variables. Thus, while the SLOOS covers only commercial banks, it seems that the survey reasonably captures the availability of credit throughout the economy as a whole.

\begin{tabular}{|c|c|c|c|c|c|c|c|c|c|c|}
\hline \multicolumn{11}{|c|}{$\begin{array}{l}\text { Table 2. Lending Standards and Financial Variables: Correlations } \\
\text { (sample: 1990Q2-2008Q1) }\end{array}$} \\
\hline \multirow[t]{2}{*}{ Standards } & \multicolumn{5}{|c|}{ Three-month LIBOR } & \multicolumn{5}{|c|}{ Real equity returns $1 /$} \\
\hline & $\mathrm{t}$ & $\mathrm{t}+1$ & $\mathrm{t}+2$ & $t+3$ & $\mathrm{t}+4$ & $\mathrm{t}$ & $\mathrm{t}+1$ & $\mathrm{t}+2$ & $\mathrm{t}+3$ & $\mathrm{t}+4$ \\
\hline Commercial and industrial & 0.19 & 0.05 & -0.10 & -0.27 & -0.41 & -0.10 & -0.20 & -0.16 & -0.09 & -0.11 \\
\hline Commercial real estate (1990Q3) & 0.14 & 0.01 & -0.13 & -0.27 & -0.39 & -0.15 & -0.12 & -0.17 & -0.20 & -0.10 \\
\hline Residential mortgage (1990Q4) & 0.03 & -0.05 & -0.12 & -0.22 & -0.32 & -0.07 & -0.05 & -0.08 & -0.06 & -0.07 \\
\hline Consumer credit & 0.13 & 0.03 & -0.07 & -0.17 & -0.24 & 0.08 & -0.02 & 0.08 & 0.18 & 0.15 \\
\hline Average standards & 0.18 & 0.06 & -0.08 & -0.24 & -0.38 & -0.11 & -0.16 & -0.10 & -0.07 & -0.07 \\
\hline \multirow[t]{3}{*}{ Bank capital-asset ratio } & -0.49 & -0.36 & -0.23 & -0.08 & 0.05 & 0.00 & 0.03 & -0.04 & 0.04 & 0.09 \\
\hline & \multicolumn{5}{|c|}{ Investment grade yield } & \multicolumn{5}{|c|}{ High yield spread } \\
\hline & $\mathrm{t}$ & $\mathrm{t}+1$ & $\mathrm{t}+2$ & $t+3$ & $\mathrm{t}+4$ & $\mathrm{t}$ & $\mathrm{t}+1$ & $\mathrm{t}+2$ & $\mathrm{t}+3$ & $\mathrm{t}+4$ \\
\hline Commercial and industrial & 0.38 & 0.37 & 0.34 & 0.27 & 0.19 & 0.84 & 0.86 & 0.86 & 0.83 & 0.71 \\
\hline Commercial real estate (1990Q3) & 0.28 & 0.30 & 0.30 & 0.27 & 0.19 & 0.66 & 0.73 & 0.69 & 0.62 & 0.54 \\
\hline Residential mortgage (1990Q4) & 0.04 & 0.07 & 0.10 & 0.10 & 0.08 & 0.19 & 0.19 & 0.16 & 0.12 & 0.07 \\
\hline Consumer credit & 0.29 & 0.30 & 0.27 & 0.21 & 0.14 & 0.51 & 0.48 & 0.42 & 0.36 & 0.21 \\
\hline Average standards & 0.33 & 0.36 & 0.37 & 0.32 & 0.24 & 0.70 & 0.77 & 0.75 & 0.69 & 0.56 \\
\hline Bank capital-asset ratio & -0.68 & -0.65 & -0.62 & -0.56 & -0.50 & -0.48 & -0.49 & -0.46 & -0.38 & -0.30 \\
\hline
\end{tabular}


Figure 2. Response of GDP to Lending Standards

(sample: 1990Q4-2008Q1)

Response in five variable VAR $\quad--++/$ - 2 Standard errors

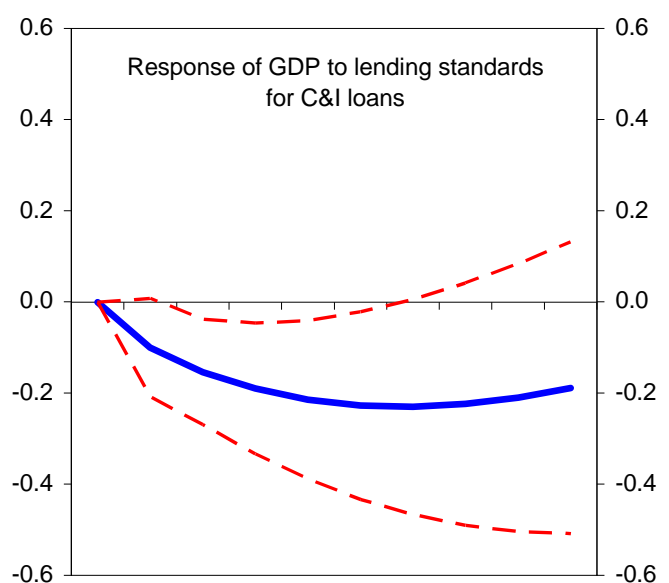

$\begin{array}{lllllllllllllll}1 Q & 2 Q & 3 Q & 4 Q & 5 Q & 6 Q & 7 Q & 8 Q & 9 Q & 10 Q\end{array}$
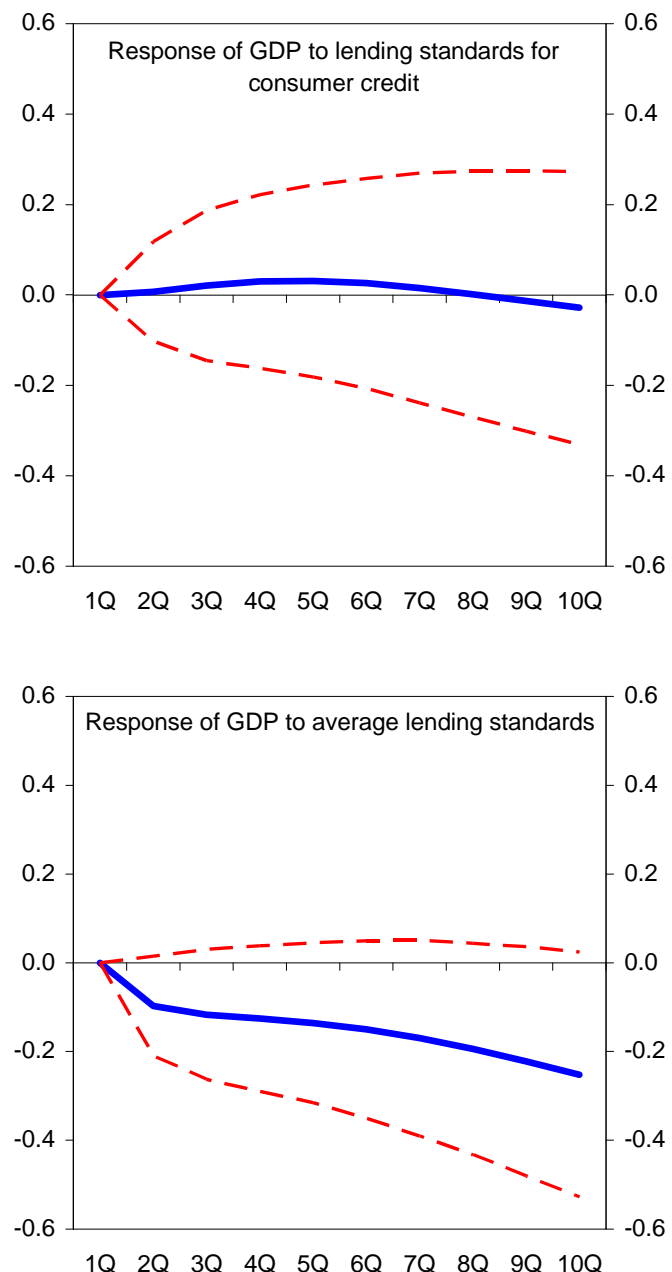

$\begin{array}{llllllllllllllllll}1 \mathrm{Q} & 2 \mathrm{Q} & 3 \mathrm{Q} & 4 \mathrm{Q} & 5 \mathrm{Q} & 6 \mathrm{Q} & 7 \mathrm{Q} & 8 \mathrm{Q} & 9 \mathrm{Q} & 10 \mathrm{Q}\end{array}$
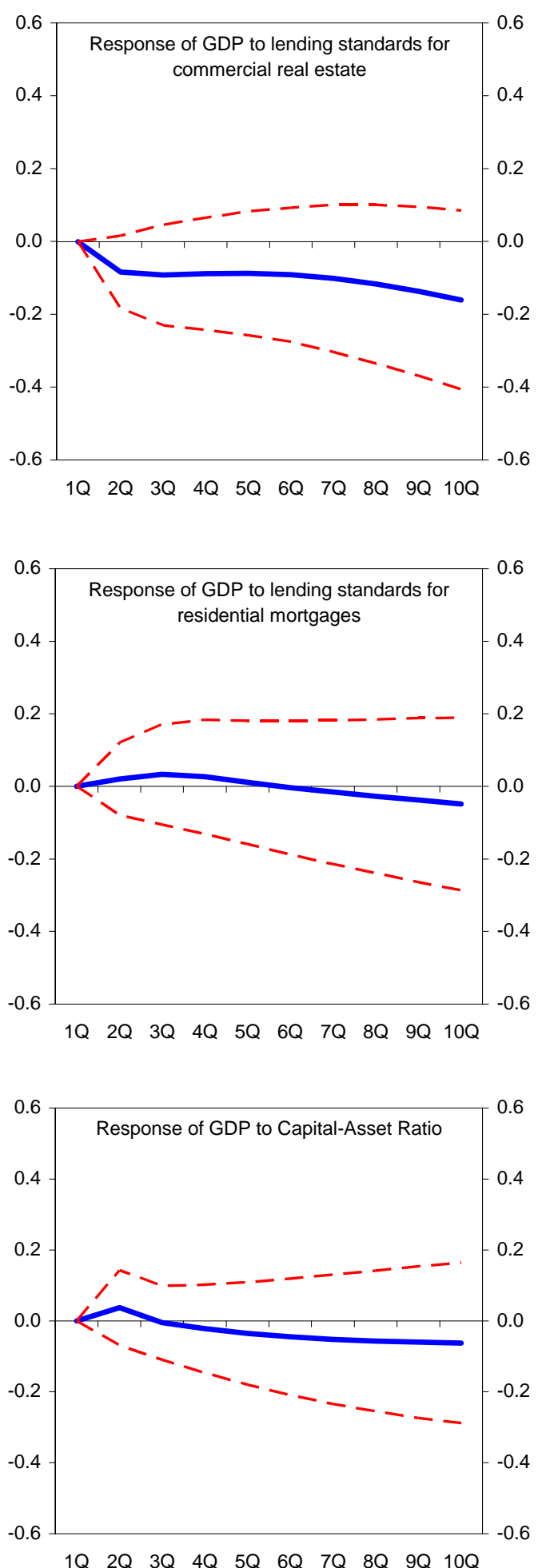

$\begin{array}{llllllllll}1 \mathrm{Q} & 2 \mathrm{Q} & 3 \mathrm{Q} & 4 \mathrm{Q} & 5 \mathrm{Q} & 6 \mathrm{Q} & 7 \mathrm{Q} & 8 \mathrm{Q} & 9 \mathrm{Q} & 10 \mathrm{Q}\end{array}$

Source: IMF staff calculations. 
Figure 2 explores whether any particular category of lending standards contains a greater degree of information about future output than the others. The panels show the response of real GDP (in percent) to a one standard deviation shock to lending standards, in a standard monetary VAR also including the GDP deflator, oil price, and three-month LIBOR. Given the finding in Bayoumi and Melander (2008) that shocks to bank capital are an important determinant of lending standards, we also include results for the risk-weighted capital-asset ratio (CAR) of the aggregate commercial banking system. An increase in the CAR implies greater capacity of banks to lend, so the expected sign is opposite that for lending standards.

Consistent with the stronger simple correlations presented above, C\&I standards are the only category of standards that has a statistically significant effect on overall economic activitythe responses of GDP to CRE and average standards are similar in magnitude, although not statistically significant, while residential mortgage standards, consumer lending standards, and the CAR are not significantly linked to GDP growth. Lown and Morgan (2002, 2006) also find that C\&I standards are significantly correlated with innovations in commercial loans at banks and with output fluctuations. For C\&I standards, a one standard deviation tightening - in this specification, amounting to 8.3 percentage points - subtracts more than 0.2 percent from GDP over the following year. The magnitude of cyclical swings in standards has ranged from about 50 to 80 percentage points, suggesting that the availability of credit plays a non-negligible role in aggregate fluctuations. Overall, C\&I standards appear to be the best single indicator of economy-wide credit availability, even when compared to a broader average across lending categories. ${ }^{10}$

\section{Which Other Variables Enter the Mix?}

Given the use of C\&I standards from the SLOOS to proxy for economy-wide credit availability, this section examines which other financial variables impact economic activity . The SLOOS for C\&I loans is only available for a short period — since 1990 — and VARs make intensive use of degrees of freedom. These issues have the drawbacks of making statistical inference difficult and not covering a large number of business cycles. ${ }^{11}$ Therefore, while statistical significance is regarded as a desirable criterion for inclusion in the FCI, lack of significance in the final specification is not considered grounds for exclusion.

The responses of GDP to a range of financial variables are first estimated individually within the standard monetary VAR from the previous section, augmented with C\&I lending standards. We then determine whether the magnitudes, if not the significance, of these responses are robust within an expanded VAR which includes other financial variables as controls. The approach taken to determining the control variables in this expanded VAR is

\footnotetext{
${ }^{10}$ Adding other financial variables to the model does not change this result.

${ }^{11}$ At the same time, the short sample minimizes the possibility of problems owing to structural breaks in any of the relationships.
} 
somewhat iterative. A variable is included if its effect on GDP is found to be correctly signed and significant, or nearly-significant, in both the narrow VAR and the expanded VAR. The other criterion for inclusion is economic significance-variables representing financial channels that are otherwise not captured are more likely to be included.

Figures 3, 4, and 5 show how variables from three broad categories-risk-free interest rates, default risk and volatility, and asset prices-affect real GDP. They show responses and standard errors from the "narrow" VARs, for which the only financial conditions included are lending standards, the short-term interest rate, and the variable under consideration. ${ }^{12}$ The response for each variable from the "expanded" VAR is also shown. The expanded VAR includes C\&I lending standards, a short-term interest rate, a long-term interest rate, risk spreads on corporate bonds, equity returns, and the real effective exchange rate (REER), as well as the variable under consideration. The specification can differ slightly by variable, as the construction of some variables requires exclusion of some of the base variables or inclusion of additional rates or spreads. ${ }^{13}$ Two lags are included in the VAR, making the estimation sample 1990Q4 through 2008Q1. ${ }^{14}$

As shown in Figure 3, the response of economic activity to monetary policy is relatively insensitive to using the overnight Federal Funds Rate, the three-month LIBOR, or the threemonth LIBOR deflated by survey results for one-year-ahead inflation. A one standard deviation shock — 22, 30, or 32 basis points, respectively — is associated with a $1 / 4$ percent decline in real GDP over a one to two year horizon. The impact of long-term risk-free rates cannot be distinguished in the narrow models, but in the expanded models, a one standard deviation shock - 25 basis points — results in a reduction in real GDP of about $1 / 4$ percent. The estimated magnitude is broadly similar whether the long-term rate is expressed as the tenyear Treasury yield, real ten-year yield deflated by survey expectations of long-term inflation, or the term premium (ten-year yield minus three-month yield).

Figure 4 shows that the spread between commercial paper and Treasury bills has had little influence on economic activity over this sample, in contrast to earlier decades (see, e.g., Stock and Watson, 1989). This possibly indicates that earlier findings were mainly reflecting certain outliers (Emery, 1996). We also fail to find a negative response of economic activity to volatility as represented by the VIX index or to the premium on mortgage lending rates.

\footnotetext{
12 The regressions for the Federal Funds Rate and LIBOR include lending standards but no additional financial variables.

${ }^{13}$ For example, the ten year Treasury yield is excluded in the expanded specification containing the investment grade bond yield, but is included in the specification for the investment grade bond spread to Treasuries.

${ }^{14}$ One or two lags were generally preferred by standard tests, with two chosen for uniformity.
} 
Figure 3. Response of GDP to Risk-Free Interest Rates

(sample: 1990Q4-2008Q1)
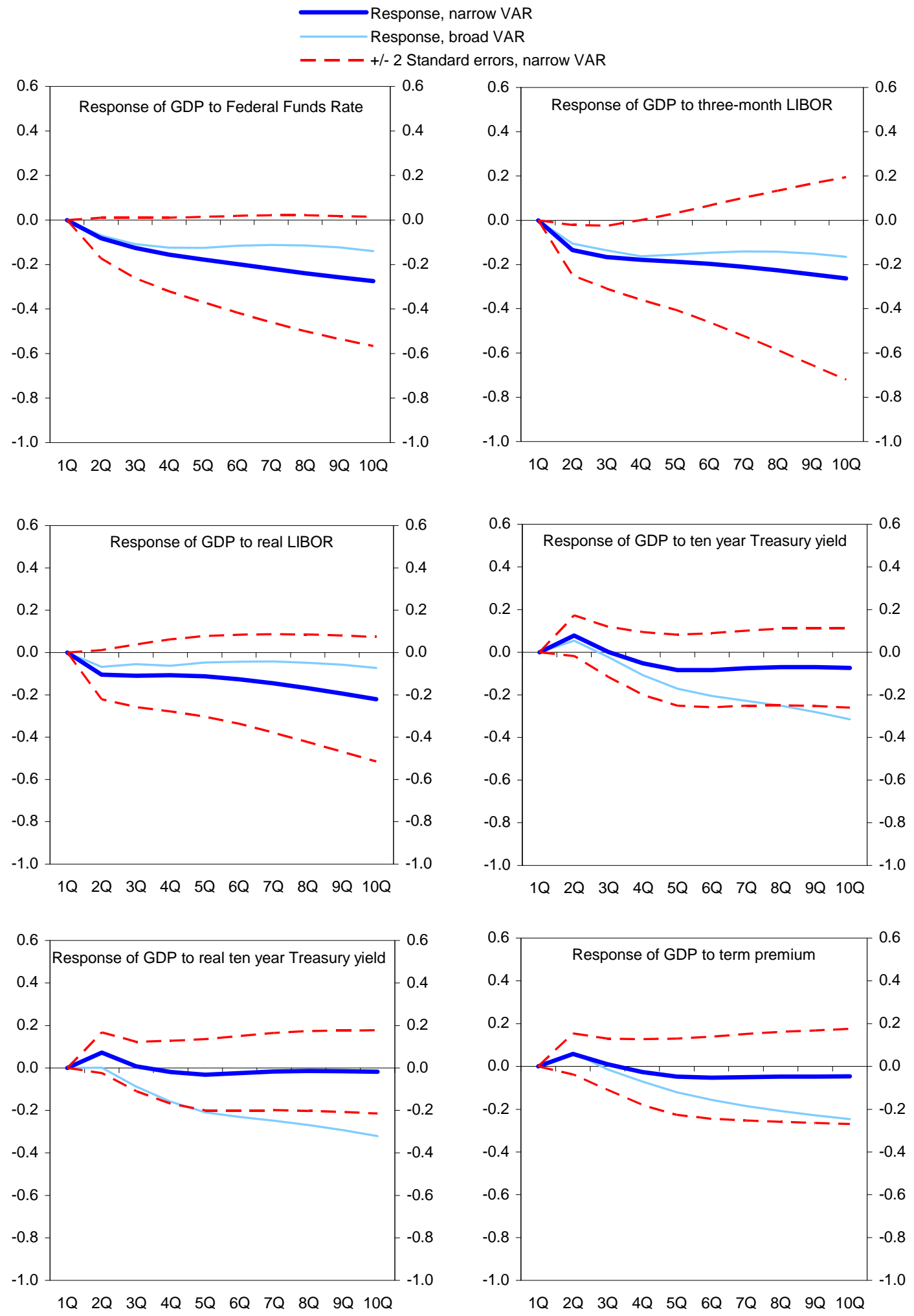

Source: IMF staff calculations. 
Figure 4. Response of GDP to Default Risk and Volatility (sample: 1990Q4-2008Q1)
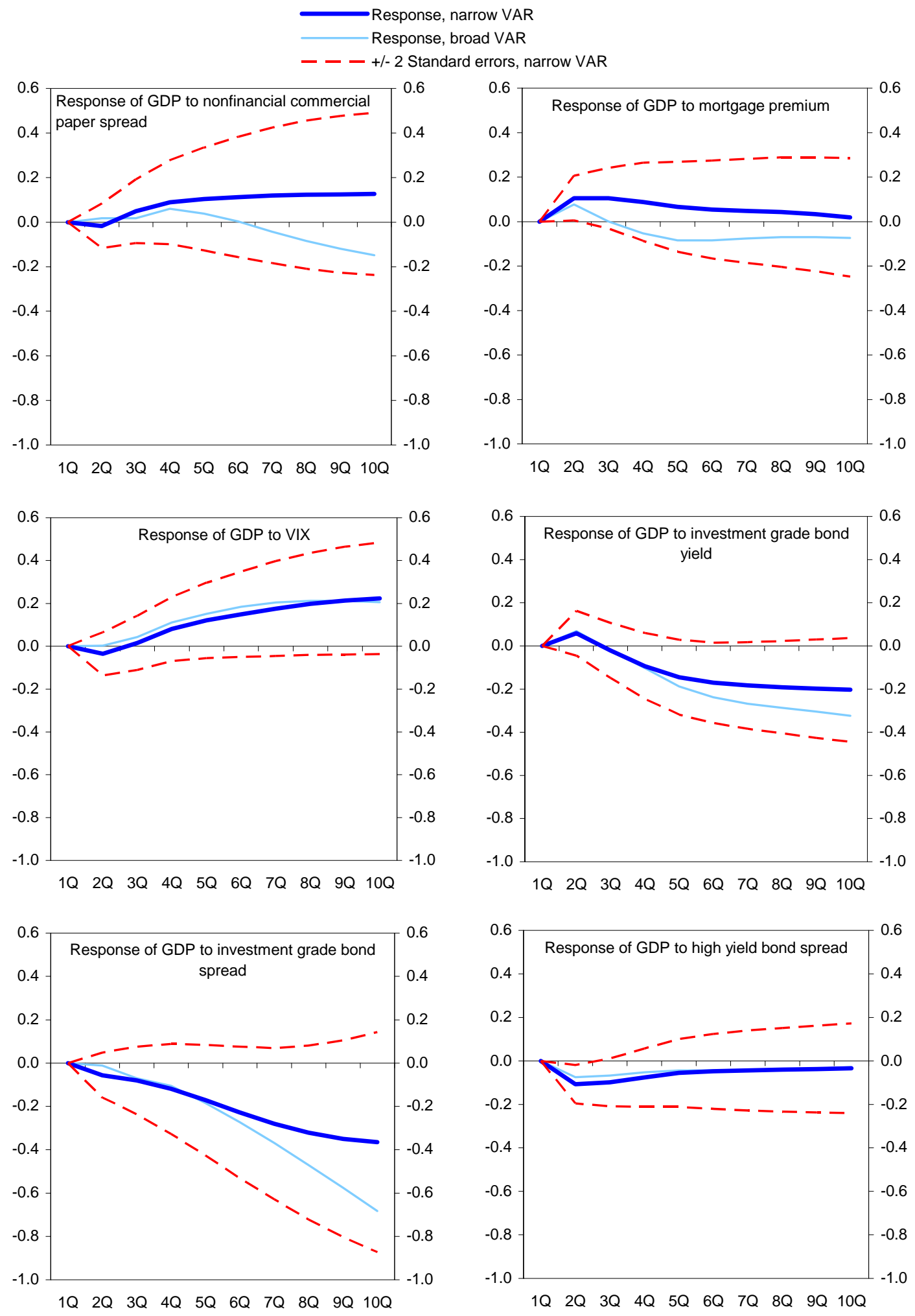

Source: IMF staff calculations. 


\section{Figure 5. Response of GDP to Asset Prices}

(sample: 1990Q4-2008Q1)
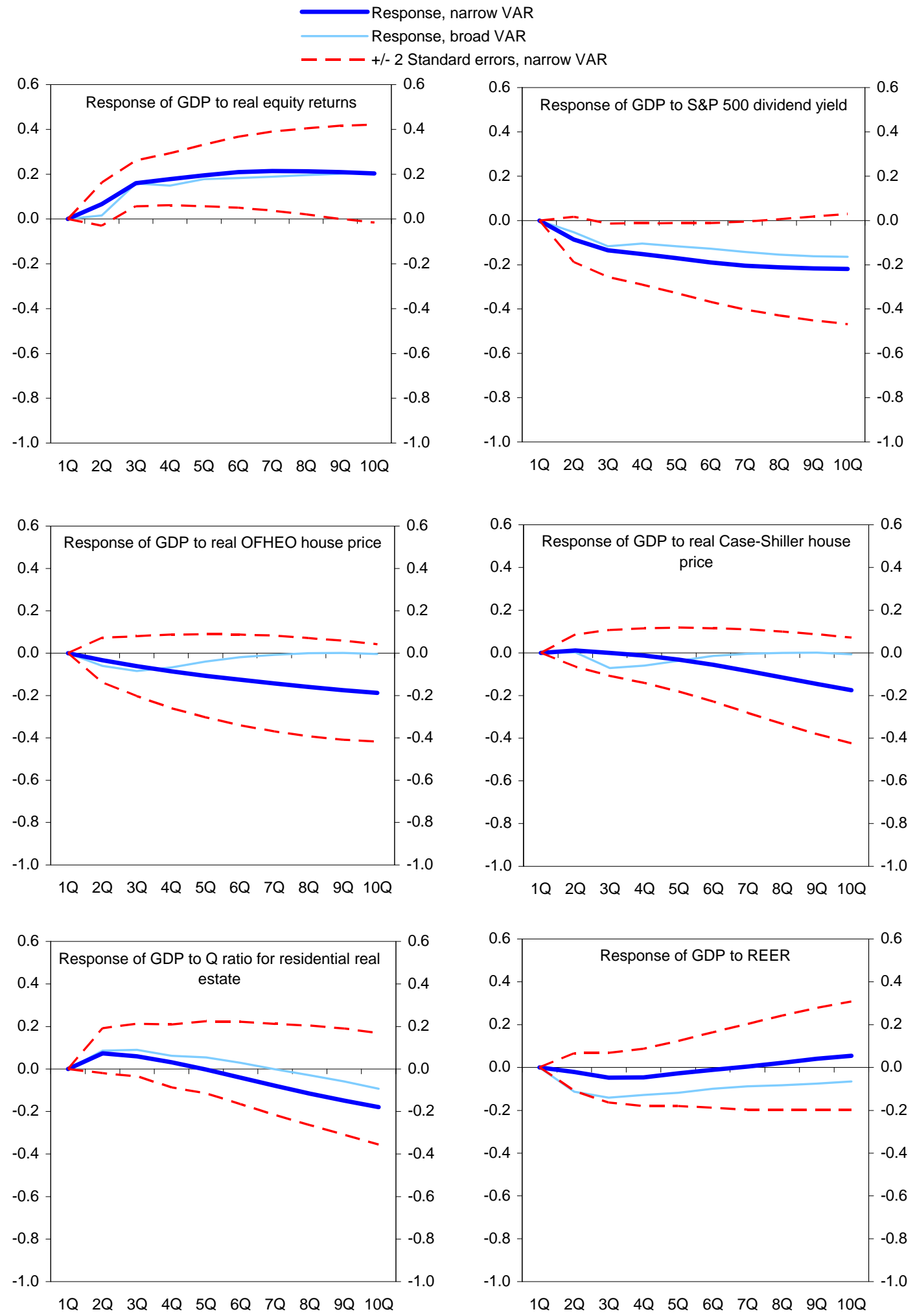

Source: IMF staff calculations. 
A one standard deviation shock to investment grade yields - again, about 25 basis pointsleads to a decline in real GDP of $1 / 4$ percent over one to two years, which is quite similar to the response for the long-term risk-free rate. The response to a one standard deviation shock to the investment grade spread is slightly larger than for the yield. The investment grade yield is included in our preferred expanded specification instead of the risk-free yield and a spread because of the similarity of the responses and to conserve degrees of freedom.

The impact of high yield spreads is small but marginally significant in the quarter after the shock. A 40 basis points rise in the spread takes a tenth of a point off GDP. The small impact contrasts with results from a model without lending standards, in which the impact is similar to that of the investment grade yield and is strongly significant. ${ }^{15}$ The reduced impact of high yield spreads on growth once accounting for credit availability using lending standards validates the interpretation in Gertler and Lown (1999) and Mody and Taylor (2003) that the correlation of high yield spreads with growth is because the spreads are one way to proxy for the availability of credit. Indeed, Table 2 shows a correlation of over 0.8 between lending standards and contemporaneous and future high yield spreads, and Figure 6 shows that movements in both variables line up closely. Lending standards' elimination of the significance of high yield spreads confirms our confidence in the survey as a good proxy for economy-wide credit availability.

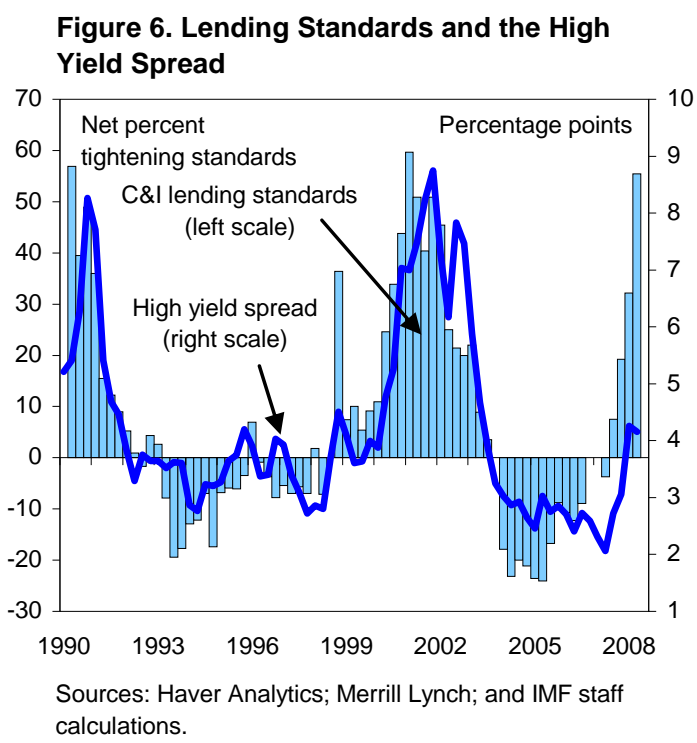

Among the prices of other assets, the response of GDP to equity returns is positive and strongly significant. A 5 percent shock to returns is associated with a 0.2 percent rise in output over the next year. Macroeconomic Advisers (1998) uses the dividend yield to proxy for corporations' equity cost of capital, and the response is the mirror image of that for equity returns, as expected. The preferred specification uses returns, as the variable is expressed in the same units as an equity price index. Several variables were examined in an attempt to capture the effect of residential real estate wealth on growth, but there was no meaningful positive response in either the narrow or expanded VARs. Finally, a stronger dollar has a mild negative impact on growth, which becomes larger and statistically significant in the expanded VAR. A one standard deviation appreciation in the REER-1.5 percent-reduces output by just over 0.1 percent.

\footnotetext{
${ }^{15}$ Lending standards continue to knock out the high yield spread even when placed last in the Cholesky ordering.
} 


\section{Financial Conditions AND Growth}

\section{A. What are the Guts of the FCI?}

This section describes the FCI, building on the above analysis of individual variables. The measure of short-term interest rates used here is the three-month LIBOR instead of the Federal Funds rate, the actual policy instrument and the usual stalwart in the literature on monetary policy shocks. For our purposes, the LIBOR has several advantages. First, the focus of this paper is more on economy-wide financial conditions than on the response to monetary policy in particular. While both the LIBOR and Federal Funds rate represent the terms of lending between banks, a significant portion of lending to non-banks is also tied to LIBOR, so it captures short-term interest rates prevailing in the markets more generally. Second, using a three-month rate implicitly includes market expectations of the monetary policy rate prevailing over that horizon. Thus, the timing of the impact of the short-term rate is based on when the market incorporates it into its expectations, not necessarily only when the Federal Funds rate is actually changed. This should more accurately translate the impact of monetary policy into real activity. Finally, recent volatility in the spread between the three-month LIBOR and expected Federal Funds rate over that horizon shows that the former incorporates counterparty and liquidity risk not captured by an overnight rate (see, for example, Taylor and Williams, 2008). We stick with nominal interest rates because of the uncertainty in properly capturing the real rate by adjusting for survey-based inflation expectations, and because the results are not greatly affected over this sample.

For long-term interest rates, we use the yield on investment grade corporate bonds with remaining maturity of five to ten years. This incorporates both the long-term, risk-free rate and the default premium for high grade corporate borrowers. Variations of the model separating these two items did not yield materially different results for the overall FCI, and the response of GDP to the yield is quite similar to the response of GDP to the corporate spread when that variable is isolated. There was little variation in the results using other corporate interest rates. This measure is mildly preferred from a theoretical standpoint, as it maintains a relatively constant average maturity, rendering it less susceptible to changes to the slope of the yield curve. Similarly, the high yield bond spread employed in the FCI comes from a weighted average of yields on corporate bonds rated BB, B, and C with remaining maturity of 5 to 10 years. The spread is taken relative to the investment grade bond yield.

Other variables in the model include real GDP, the GDP deflator, oil prices, equity returns, and the real effective exchange rate. The measure of equities is the total return on the S\&P 500 index (including reinvested dividends) deflated by the GDP deflator. The real effective exchange rate (REER) is the trade-weighted broad index produced by the Federal Reserve.

The FCI is estimated as in the previous section, using a VAR containing two lags. Interest rates/spreads and lending standards enter the VAR in levels, while all the other variables 
have been transformed into logs. This specification follows Bernanke and Gertler (1995) and Christiano et al (1996), among other authors. ${ }^{16}$ Recall that lending standards are implicitly expressed as a change, the proportion of banks either tightening or easing standards. However, the time series is highly persistent, suggesting that to some extent, the responses reflect participants' views on the absolute level of standards. At any rate, there was no difference in the results when using the cumulated level of standards.

Given the previous discussion on the timing of the SLOOS, lending standards are placed first among the financial variables, directly after output, inflation, and oil prices. Similarly, monetary policy decisions in the United States usually occur once every six weeks. New information that affects expected overnight rates typically only moves the rate expected to prevail after the upcoming monetary policy decision. Thus, the three-month LIBOR contains some element of fixity even on a quarterly basis and are placed after standards. There is no clear consideration elevating any of the other variables in the ordering, but experimentation with various schemes didn't produce noticeably different results. In these results, the REER, the investment grade yield, high yield spread, and equity returns follow LIBOR.

\section{B. Which Financial Conditions Matter?}

Figure 7 presents IRFs showing the impact on real GDP of each of the six financial variables included in the model. Each panel shows two responses. The thick line shows the response from the model with all six financial variables, plus the associated \pm 2 standard error bands. The thin line is the response of GDP from the "narrow" model used in the previous section, which contains only real GDP, the GDP deflator, the oil price, lending standards, threemonth LIBOR, and the variable in question.

The broad results highlight the strong influence of lending standards on growth, with statistically significant effects also coming from equity returns, investment grade corporate yields, and the REER. A one standard deviation shock to C\&I lending standards, which is a net tightening of 6.8 percentage points, reduces GDP growth over the next year by $1 / 4$ percentage point. ${ }^{17}$ This is slightly smaller than the impact in Lown and Morgan (2002, 2006), although their analysis also covers 1967 to 1983. Bayoumi and Melander (2008) report a similar magnitude to ours using a very different methodology.

The role of lending standards in driving economic activity, even when accounting for the information on future growth contained in other financial markets, is strong evidence that the variable is not just capturing forward-looking behavior on the part of bank loan officers. One

\footnotetext{
${ }^{16}$ Expressing the variables in changes shifts some explanatory power from investment grade yields to high yield spreads, but the major findings presented here are the same.

17 The response is hardly affected by placing standards last in the Cholesky ordering. This alternate ordering raises the response of GDP to monetary policy, while reducing the impact of investment grade yields and high yield spreads, but leaves the main results unchanged.
} 
interpretation of the high partial correlations between lending standards and growth presented earlier is that bank loan officers could foresee an economic slowdown and tighten credit availability to prevent future losses, but that there is little causal effect of credit supply on growth. If this hypothesis were correct, the impact of standards on economic activity should be greatly reduced in a multivariate framework, as equity prices, bond yields, and the setting of monetary policy would all contain much of the same forward-looking information. However, the results presented here lend absolutely no support to that story, instead indicating that there is at least some element of causality from credit availability to output.

Among the other variables, one standard deviation shocks to investment grade bond yields (24 basis points) and equity returns (5.3 percent) each take off 0.2 percent from GDP growth over the next year. The impact of REER appreciation, while statistically significant in the first year, is smaller, perhaps because income effects outweigh some of the growth-reducing impact of expenditure-switching. The response of GDP to three-month LIBOR is not statistically significant in the expanded VAR, but a 30 basis points shock still reduces GDP by 0.16 percent over the following year. This response to monetary policy is about the same as in Bernanke and Gertler (1995) and smaller than that obtained by Lown and Morgan (2002) and Christiano et al (1996), but the magnitude of estimated shocks is smaller as well, because the sample here excludes the volatile 1970s and early 1980s.

Figure 7 shows that the point estimate for the response of GDP to lending standards increases when the other financial variables are included, nearly doubling at the two year horizon. This suggests that a narrow focus on the impact of credit availability without accounting for the endogenous response of other financial markets can understate the contractionary impact of a cutoff in credit supply.

Figure 8 reports the responses of financial variables to a lending standards shock and confirms that other financial markets accentuate the effects of restrictions in credit supply. Aside from the monetary policy easing brought about by the reduction in credit availability (which is included in the narrow model), the effects of a credit squeeze on growth are heightened by a sharp rise in high yield spreads and a significant decline in equity returns. This is mitigated to some extent by a mild depreciation of the dollar, and, over time, a reduction in investment grade yields, but the overall effect of incorporating other financial variables into the analysis is to magnify the impact on growth of a tightening of lending standards. ${ }^{18}$ Estimates of the effects of credit availability on economic activity will thus tend to contain a downward bias unless they account for shock amplification by financial markets. Figure 8 also shows that the financial market response to a credit crunch is not very sensitive to the ordering of lending standards in the IRFs_-putting lending standards last does not notably alter the findings.

\footnotetext{
${ }^{18}$ Analysis in a VAR that disaggregates the investment grade yield into the risk-free Treasury yield and the corporate risk premium shows that the former falls as monetary policy eases, while the latter rises.
} 
Figure 7. Response of GDP to Financial Shocks

Response, expanded VAR
Response, narrow VAR

$--\ldots+/-2$ Standard errors, expanded VAR

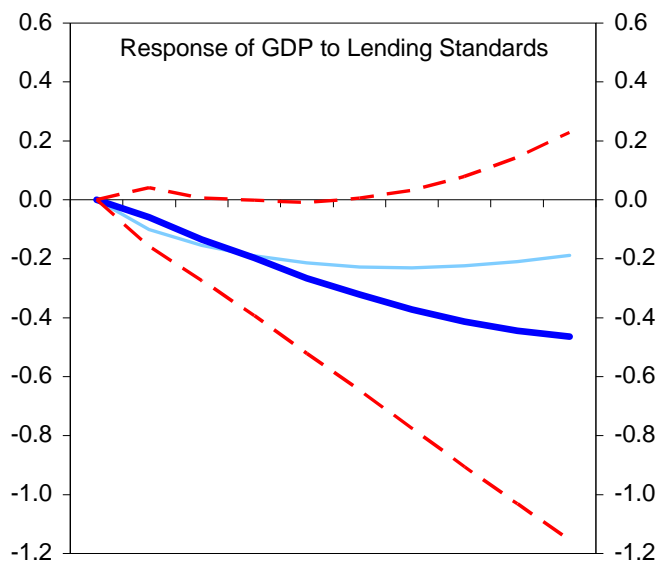

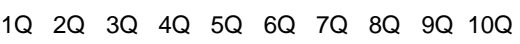

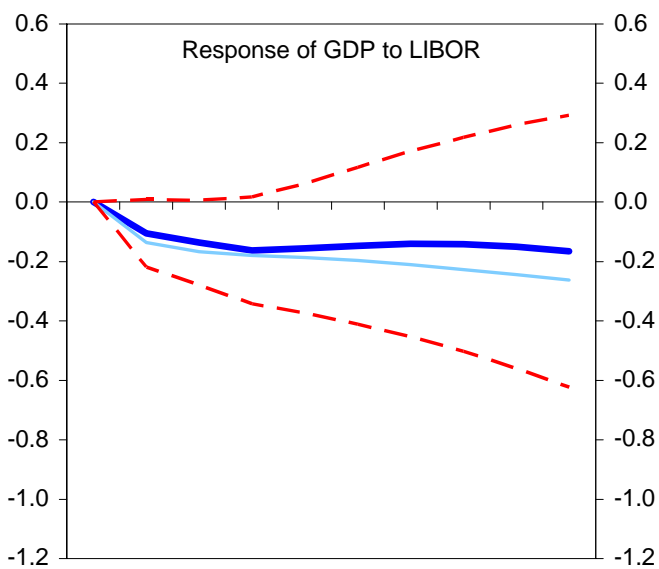

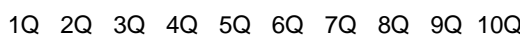
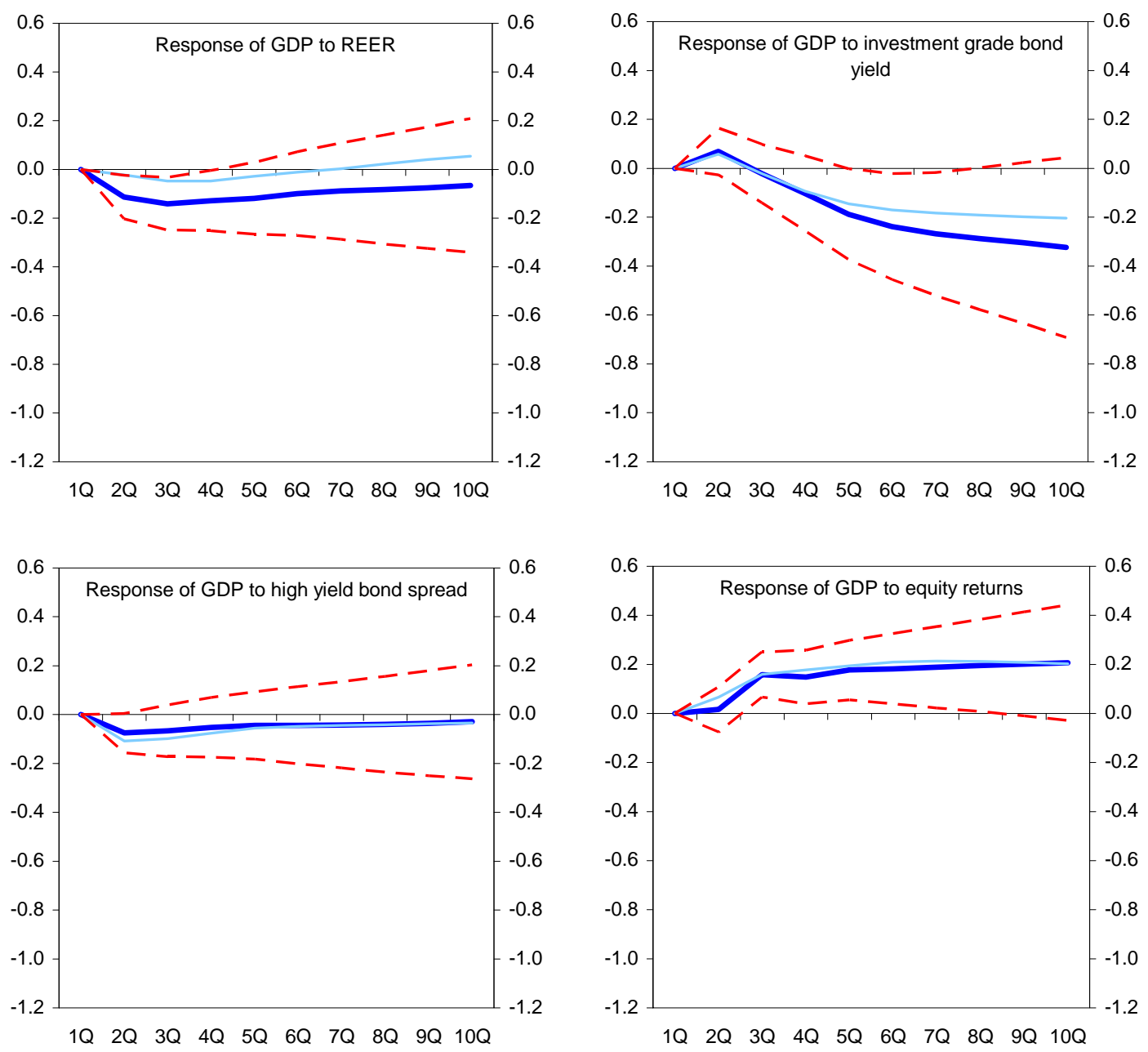

Source: IMF staff calculations. 
Figure 8. Response of Financial Conditions to Lending Standards

Response, lending standards first
Response, lending standards last

$-\ldots++-2$ Standard errors, lending standards first

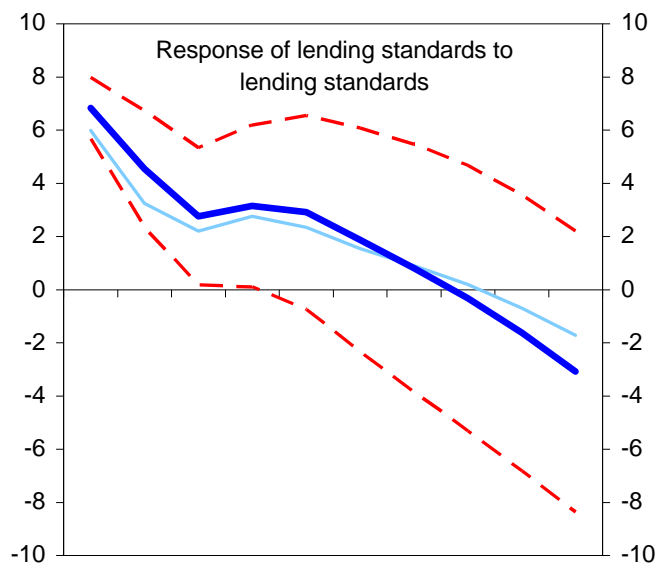

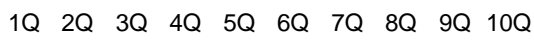
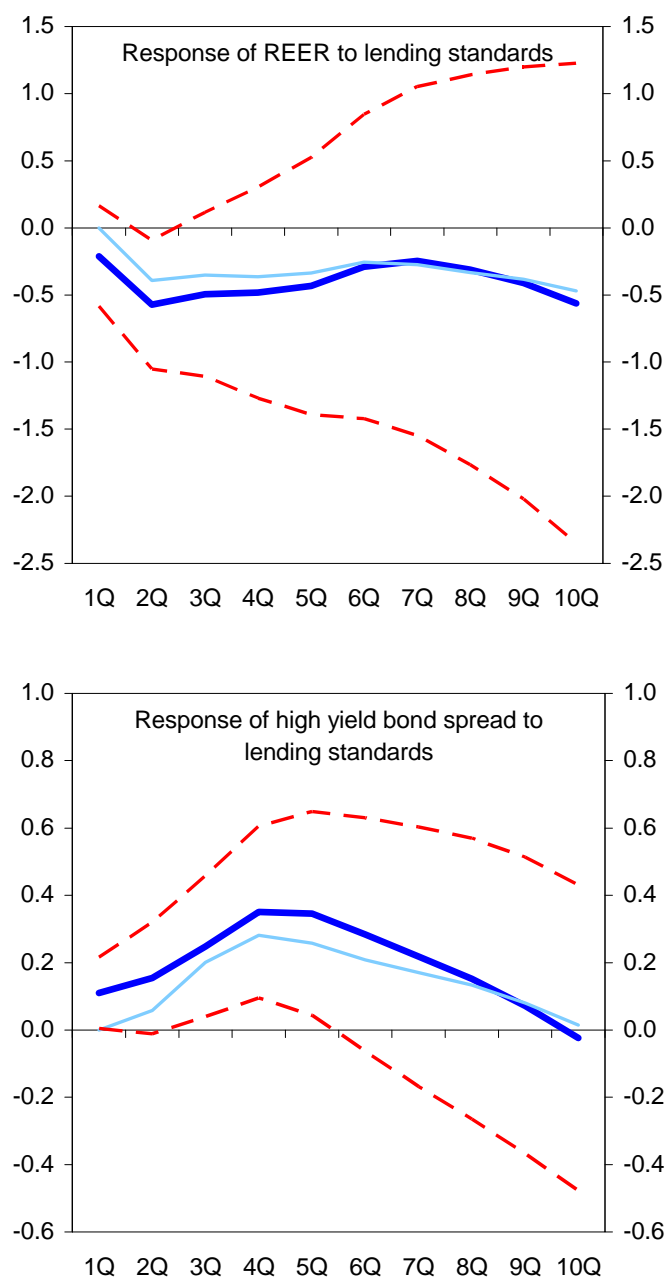

$\begin{array}{lllllllllllllllllllll}2 \mathrm{Q} & 3 \mathrm{Q} & 4 \mathrm{Q} & 5 \mathrm{Q} & 6 \mathrm{Q} & 7 \mathrm{Q} & 8 \mathrm{Q} & 9 \mathrm{Q} & 10 \mathrm{Q}\end{array}$

Source: IMF staff calculations.

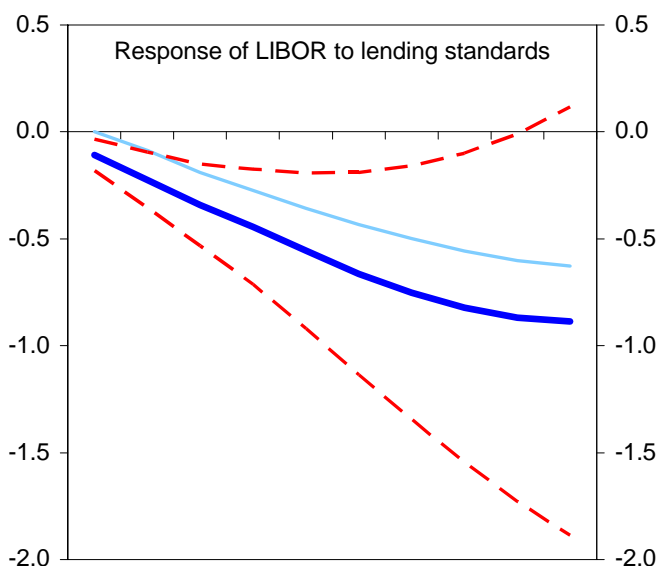

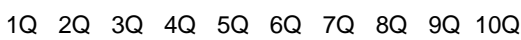
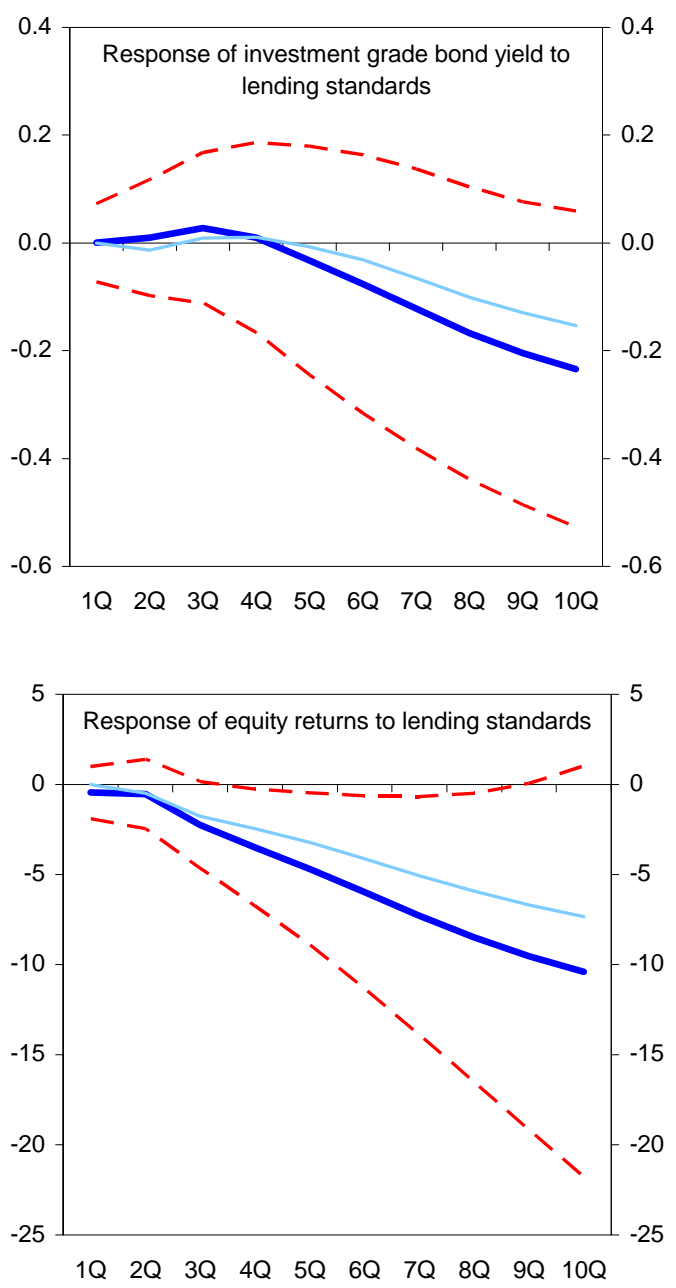
The estimated impact of monetary policy on growth is also heavily influenced by the inclusion of lending standards. Figure 9 shows the response of GDP to three-month LIBOR from three specifications - a small monetary VAR without lending standards, the same VAR adding all financial variables except standards, and the expanded VAR including standards (as in Figure 7). The impact of short-term interest rates on economic activity is basically zero unless lending standards are included, while adding other variables to the model has much less of an impact on the estimated response. ${ }^{19}$ Recall from Figure 8 that monetary policy responds aggressively to shifts in credit supply. A model without credit availability could see monetary

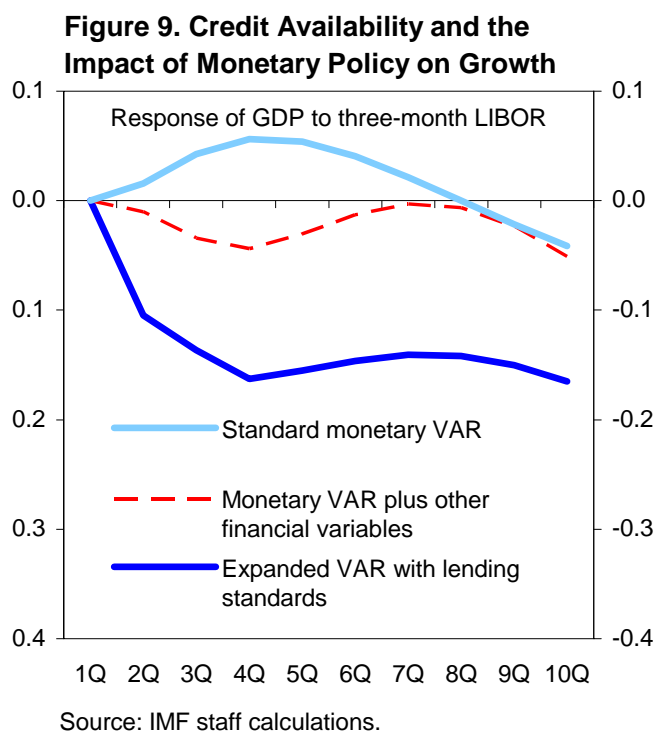
easing, for instance, as a shock that fails to produce a pickup in growth, when it is actually an endogenous response to a cutoff in credit availability, which is the true source of the economic weakness. Neglecting the relationship between credit availability and monetary policy will thus tend to bias the response of GDP to short-term interest rates toward zero.

The importance of lending standards in identifying effects from short-term interest rates suggests that since 1990 some of the impact of monetary policy has worked through a tightening in credit supply. This is evidence supporting the existence of a credit channel of monetary policy. Indeed, the recent grinding to a halt of the U.S. securitization system and associated freezing of credit markets followed, with some lag, a period of sustained monetary tightening. While other factors were clearly dominant, the order of events at least does not rule out some role for monetary policy via the availability of credit.

\section{What Role for Credit Aggregates?}

Lending standards remain a driving force in the business cycle even in a multivariate analysis, but this may not imply that they completely capture shifts in the supply of credit. If credit quantities contain additional explanatory power for growth beyond that provided by lending standards and price variables, then this would suggest that the SLOOS might not entirely encompass all credit supply factors.

The SLOOS’ properties as a reasonable proxy for credit supply are examined by augmenting the preferred specification from above with several different credit aggregates. Each variable is examined individually in a separate run of the VAR to preserve degrees of freedom. Each panel in figure 10 shows two IRFs, one in which the quantity of credit is placed after lending standards and LIBOR in the Cholesky ordering, and a second in which credit is placed before all the financial variables, with standard error bands shown for the former specification.

\footnotetext{
${ }^{19}$ Replacing the LIBOR with the Federal Funds rate produces the same results.
} 
Figure 10. Response of GDP to Credit Aggregates
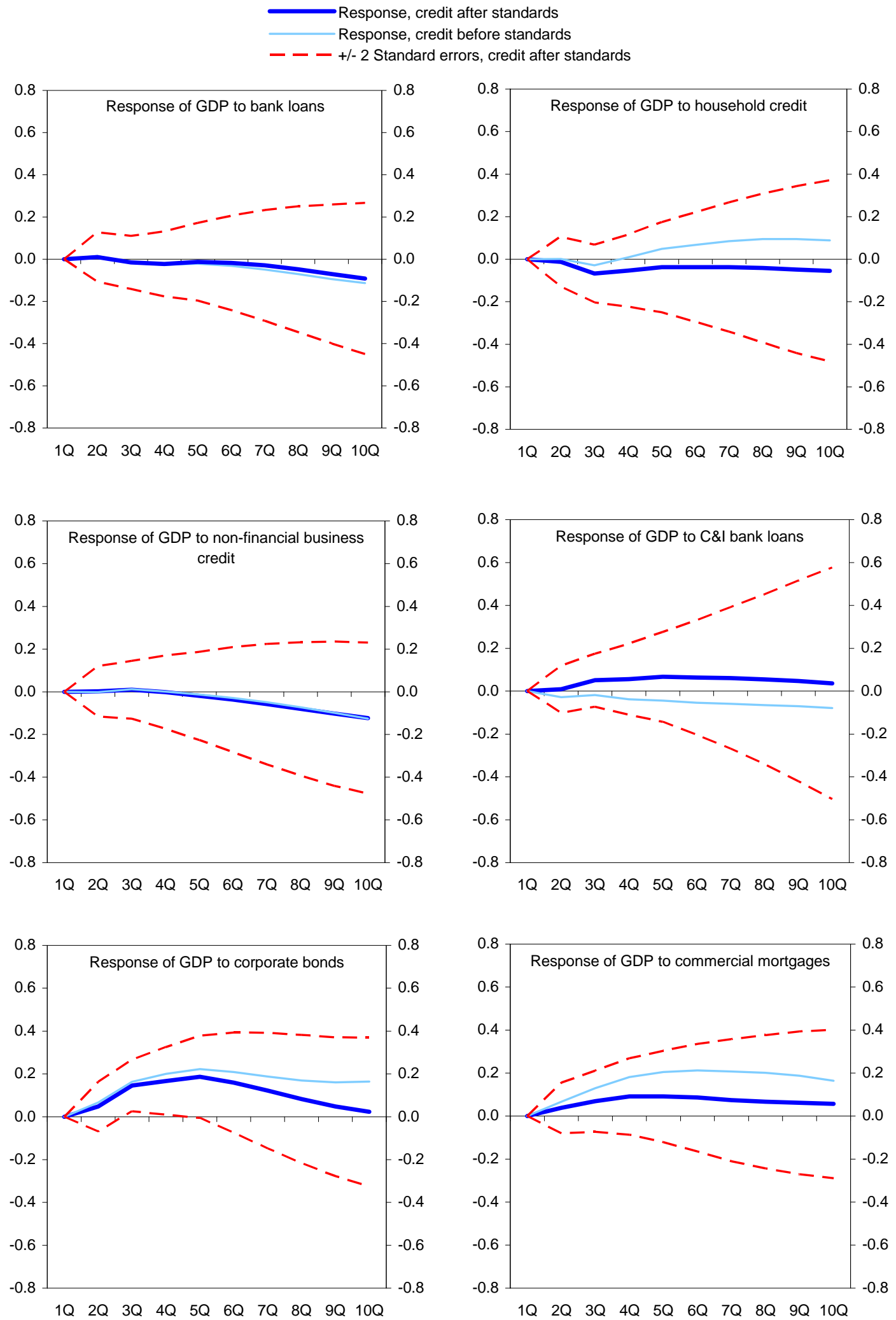

Source: IMF staff calculations. 
Figure 10 indicates that broad credit aggregates provide little information about the future direction of the economy, but certain categories of credit contain some explanatory power. Neither bank loans, total household credit (residential mortgages and consumer credit), nonfinancial business credit, nor loans from commercial banks to non-financial business have statistically or economically significant effects on growth. Disturbances to the quantity of corporate bonds, however, have a positive impact on growth over roughly a year. The response of GDP to commercial mortgages varies more across specifications, with the stronger response seen when they are earlier in the VAR a possible sign that this category of credit captures some of the same credit constraints contained in lending standards. Overall, though, these results back up the validity of the SLOOS as a solid proxy for non-price credit availability throughout the financial system, as the quantity of credit provides little additional explanatory power.

\section{What is the FCI's Contribution to Growth?}

The IRFs shown in Figure 7 can be combined with an estimate of the shocks to each variable to calculate the total impulse to growth in a given quarter. Our FCI includes the effects on GDP of shocks to the financial variables from the previous eight periods. Figure 7 shows that the IRFs have mostly leveled out at that horizon, and two years seems a reasonable period within which all financial shocks will have worked into economic activity. The FCI is thus the sum of 48 separate terms, capturing the impact of each of six variables from each of the previous eight quarters.

Measurement of the FCI in terms of its contribution to growth means that both the level of the index and the direction of recent changes have implications for economic activity. A value of 1 , for example, means that the total impulse of financial conditions to GDP in a given quarter is one percentage point, annualized. A decline in the FCI from 1 to $1 / 2$ would be expected to pull $1 / 2$ percentage point from growth, but the total contribution to growth is still positive. Thus, a distinction can be drawn between tight financial conditions and tightening financial conditions that are still accommodative.

Given the 1990Q2 start of the SLOOS question on C\&I loan standards, the two lags included in the VAR, and the eight lags necessary to calculate the FCI's impact on growth, the quarterly FCI series starts in 1992Q4. The four quarter moving average FCI, which we compare with y/y real GDP growth, thus begins in 1993Q3. We also calculate an FCI using the financial shocks from only four quarters. This alternate FCI lines up well with the preferred specification in most periods, including early in the sample, so we use this to extend the FCI back to 1992Q3 for some uses.

The FCI we estimate accounts for a substantial portion of the variation in real GDP growth over the business cycle (Figure 11). The correlation between y/y real GDP growth and the four-quarter-average FCI is 0.68; even the correlation between the quarterly FCI and quarterly annualized growth is 0.47 (Table 3). These correlations exceed those of any 
individual component, supporting Stock and Watson's (2003) finding that forecasts combining several financial variables can improve upon univariate forecasts.

Figure 11. Financial Conditions Index

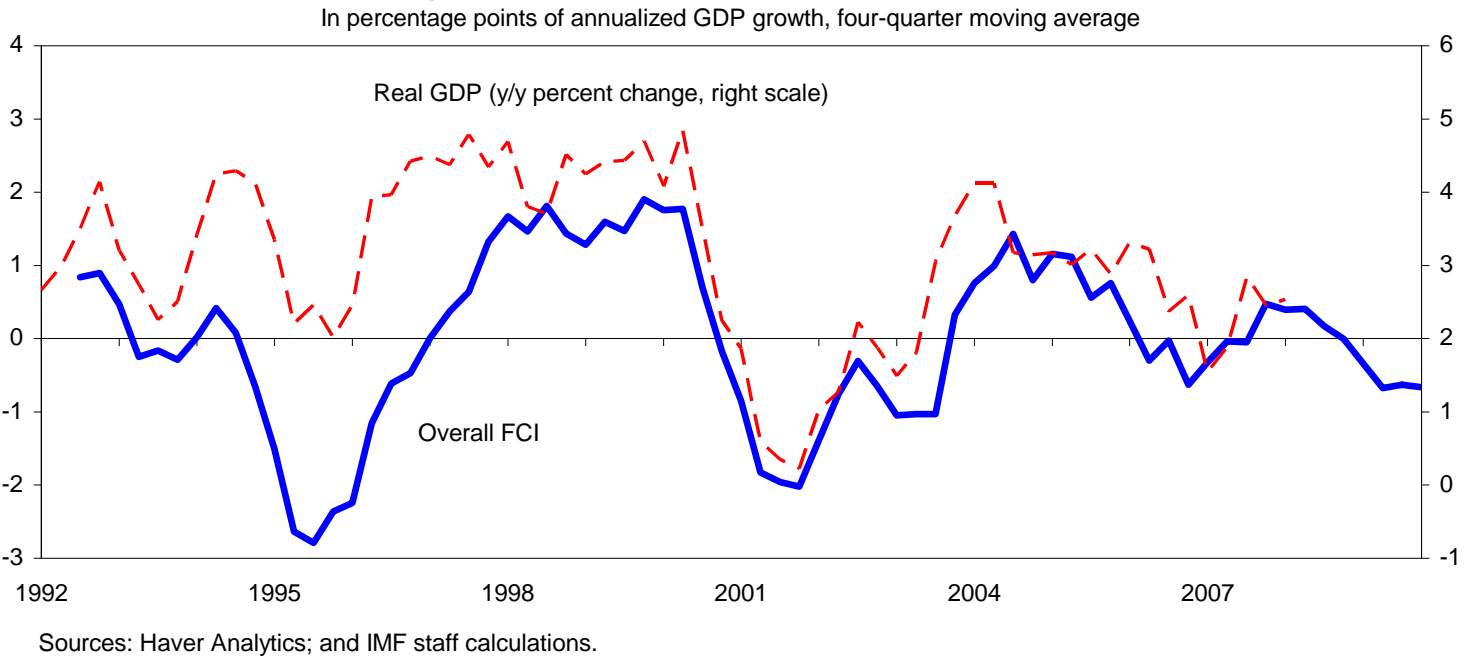

Sources: Haver Analytics; and IMF staff calculations.

\begin{tabular}{|c|c|c|c|c|}
\hline \multicolumn{5}{|c|}{$\begin{array}{l}\text { Table 3. Financial Conditions and Real Activity: } \\
\text { Correlations and Variance Decompositions }\end{array}$} \\
\hline \multirow[b]{2}{*}{$\begin{array}{l}\text { Financial variable } \\
\text { (contribution to FCI) }\end{array}$} & \multicolumn{2}{|c|}{$\begin{array}{c}\text { Correlations } \\
\text { Real GDP growth }\end{array}$} & \multirow{2}{*}{$\begin{array}{c}\text { Variance decompositions } \\
\text { Real GDP } \\
\text { Eight quarters } \\
\text { ahead }\end{array}$} & \multirow{2}{*}{$\begin{array}{c}\text { Average absolute } \\
\text { contribution to FCI } \\
\text { Percent of total }\end{array}$} \\
\hline & $\begin{array}{c}\text { Quarterly } \\
\text { annualized }\end{array}$ & $\begin{array}{l}\text { Year-on- } \\
\text { year }\end{array}$ & & \\
\hline Overall FCI & 0.48 & 0.68 & .. & .. \\
\hline Leading FCI & 0.47 & 0.67 & .. & .. \\
\hline Lending standards & 0.25 & 0.43 & 30.4 & 22.0 \\
\hline LIBOR & 0.27 & 0.23 & 6.7 & 12.9 \\
\hline REER & 0.21 & 0.49 & 3.8 & 12.7 \\
\hline Investment grade yield & 0.33 & 0.57 & 14.6 & 27.7 \\
\hline High yield spread & 0.19 & 0.30 & 0.9 & 6.2 \\
\hline Real equity returns & 0.15 & 0.34 & 9.3 & 18.5 \\
\hline
\end{tabular}

Looking at the path of the FCI over time, financial conditions tightened sharply in 1994 and 1995, contributing to a slowdown in growth. Economic activity picked up again in 1996 and 1997 as the FCI improved, and growth was robust from 1998 through 2000 as financial conditions remained accommodative. The recession of 2001 coincided with another plunge in the FCI, and output in the subsequent recovery also closely tracked financial conditions. 
Even the brief rebound in growth in mid-2007, a period for which many forecasters had predicted recession, was not entirely unanticipated by the FCI, as its contribution to growth reversed from a low point at the end of 2006.

Table 3 highlights the importance of credit availability to the FCI and to the business cycle. Lending standards explain 30 percent of the variance of real GDP over the cycle, twice as much as the next closest variable, investment grade yields. Standards are second only to investment grade yields in their average absolute contribution to the FCI.

Figure 12 shows each financial variable's quarterly profile of shocks and the time series of its overall contribution to the FCI. It should be noted that these shocks represent the difference between the actual outcome and that predicted by the VAR, so that the shock to a variable can be negative for growth even if the variable itself is becoming more accommodative, although the relationship between the direction of change in the variables and the sign of the VAR residuals is usually intuitive. ${ }^{20}$ The lines in Figure 12 sum up the impact on growth of shocks to the previous eight quarters and take the four-quarter moving average, for comparison to the overall FCI in Figure 11. Figure 13 expresses the lines from Figure 12 in columnar form, displaying the contributions to the FCI from each individual variable at any given point in time. The following findings stand out:

- $\quad$ The growth slowdown in 1995 was largely the product of the sharp increase in longterm interest rates in 1994. The ten-year Treasury yield rose from 6.1 to 7.8 percent from Q1 to Q4 1994, raising long-term corporate yields by an equivalent amount, pushing up high yield spreads, and causing a decline in real equity returns. The FCI tightened by 2.8 percentage points from 1994Q3 to 1995Q3, with over 80 percent of the shift accounted for by changes in corporate bond rates (both investment grade yields and high yield spreads) and real equity returns.

- Variation in credit availability contributed significantly to the late 1990s boom and the early 2000s bust. Lending standards added 1 percent to growth at the peak in late 1998, before a tightening owing to the Asian and LTCM crises sent the contribution downward. The distance from peak to trough was $1 \frac{1}{2}$ percentage points, and the continued drag from lending standards was one factor holding down growth in 2002.

- The contribution from investment grade yields paralleled that of lending standards from the late 1990s through the early 2000s, boosting growth from mid-1996 through mid-2000. The rise in yields from late 1998 through early 2000, and an increase in spreads in 2000 and 2001 caused the contribution to swing by 11/2 percentage points between mid-2000 and mid-2001.

\footnotetext{
${ }^{20}$ As a counterexample, shocks to the three-month LIBOR were positive throughout 2007, even though the rate was steady for the first three quarters, and fell in Q4, as the value implied by the model was lower than the actual throughout the year.
} 
Figure 12. Financial Shocks and Contributions to the $\mathrm{FCl}$

$\square$ Quarterly shock (left scale; units indicated in each panel)

Contribution to $\mathrm{FCl}$ (right scale; percentage points of y/y real GDP growth)
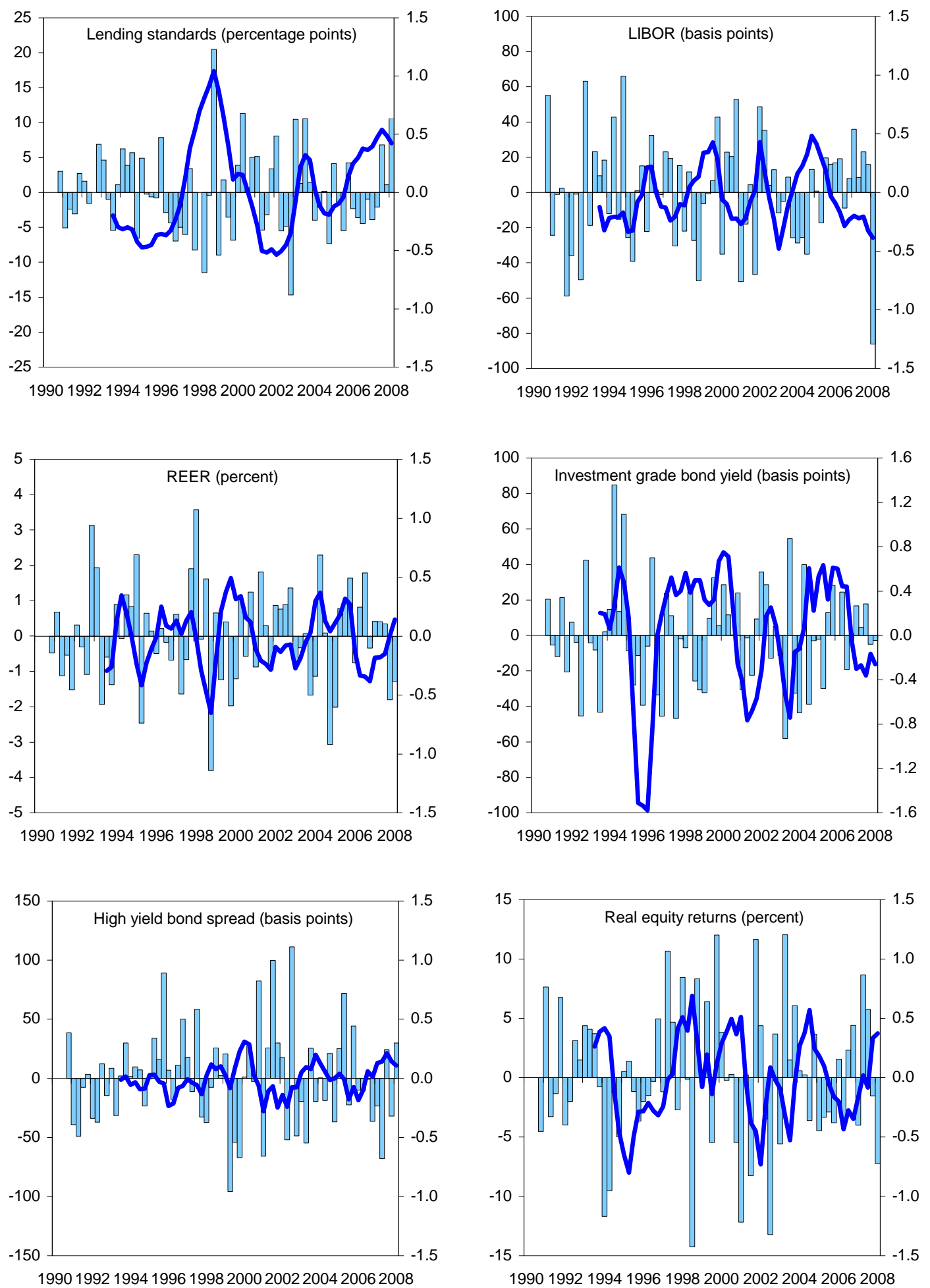

Source: IMF staff calculations. 
Figure 13. Individual Contributions to the $\mathrm{FCl}$

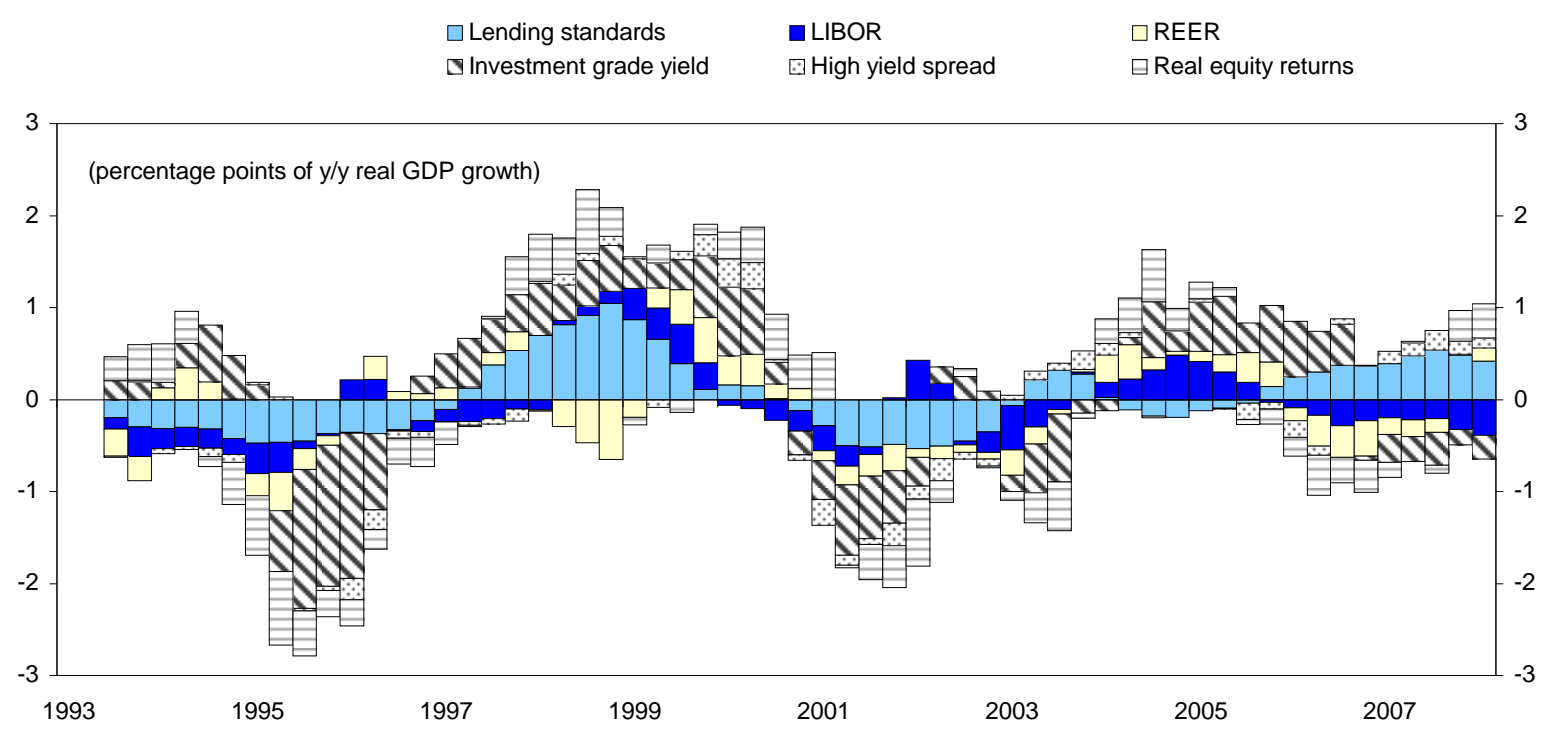

Source: IMF staff calculations.

- While monetary policy actions were often coincident with or leading the cycle over this period, the lagged impact of previous tightening or easing often negated the impact of these actions on growth. For instance, the rapid policy easing beginning in January 2001 took time to reverse the effects of previous tightening, as the contribution from LIBOR remained negative until the fourth quarter of the year, when the recession was ending.

- The contribution of real equity returns is more volatile, but the bull market of the late 1990s did add to growth and the downturn starting in 2000 pulled down growth, especially at the bottom of the cycle. The contributions of the real exchange rate and high yield spreads also display less persistence, and neither variable is a major driver of the cycle.

- Lagged transmission effects are often important. For instance, the overall impact of lending standards on economic activity in late 2007 and early 2008 was positive, as the boost to growth from easy credit conditions in earlier periods outweighed the drag resulting from the onset of credit market turmoil in August 2007. ${ }^{21}$

\section{E. Where Do Financial Conditions Hit Hardest?}

We have shown above that lending standards, long-term interest rates, equity returns, and monetary policy all exert important influences on economic activity over the business cycle. One would expect these variables to have differing impacts on the various components of demand to the extent that each component relies on that particular financial market as a

\footnotetext{
${ }^{21}$ The four-quarter moving average FCI also presents a slightly elongated picture of the lags relative to the quarterly impact on growth.
} 
Figure 14. Response of Components of Demand to Financial Shocks
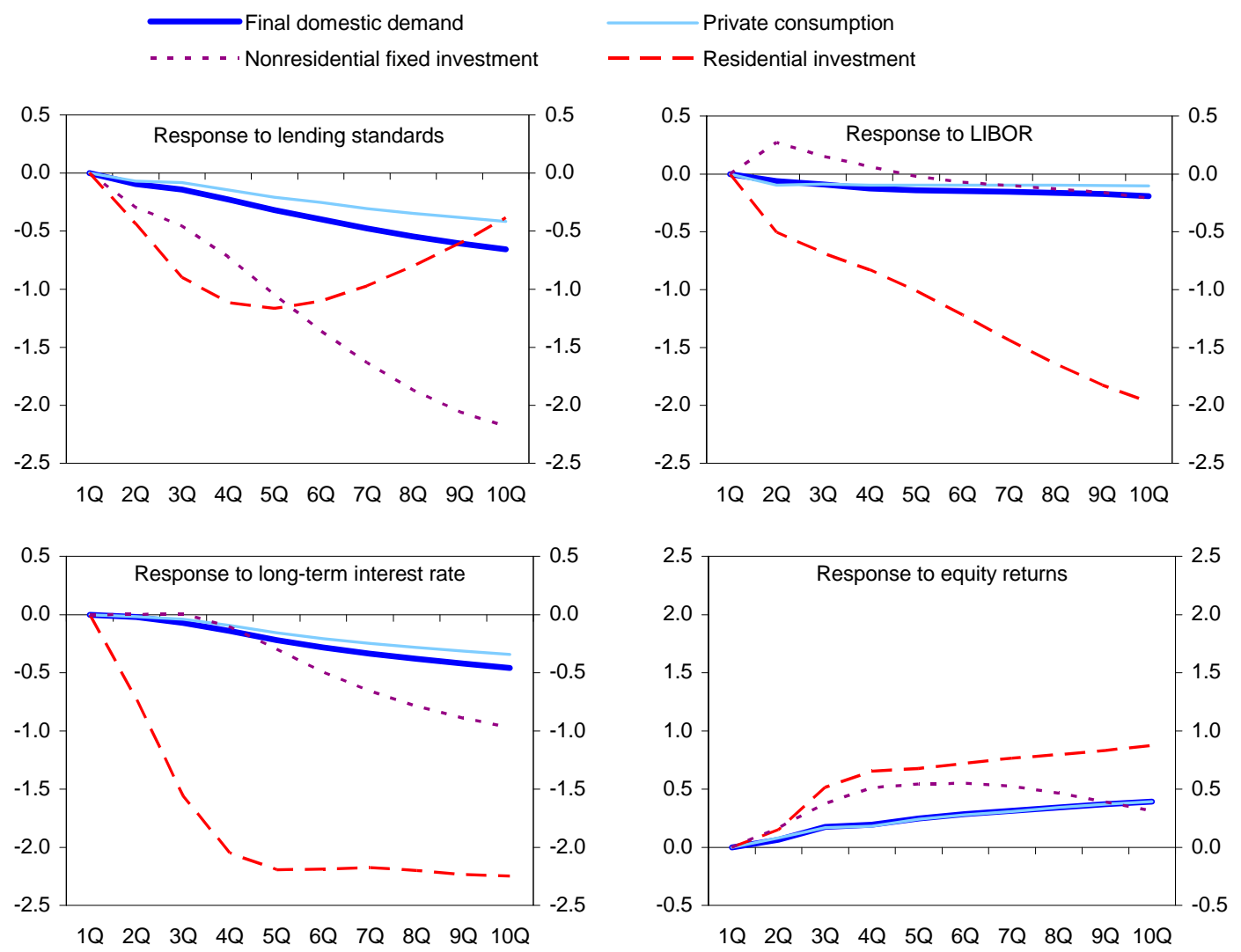

Source: IMF staff calculations.

source of financing. Bernanke and Gertler (1995) show, for instance, that residential and nonresidential fixed investment are much more interest-sensitive than consumption of nondurables, and Lown et al (2000) find that lending standards have a larger impact on business fixed investment than on overall industrial production.

Credit availability has a particularly strong impact on nonresidential fixed investment, while residential investment is the most sensitive to other financial conditions. The same VAR format as above is employed, replacing GDP and its deflator with each component of final domestic demand and its deflator. ${ }^{22}$ Figure 14 shows the response, in percent, to a one standard deviation shock to each of the main variables in the FCI.

The following results are noteworthy:

- A tightening in lending standards causes both residential and nonresidential fixed investment to fall, but the former bounces back after a year, while the latter continues declining for over two years. It eventually falls by more than 2 percent.

\footnotetext{
${ }^{22}$ The VAR for residential investment also replaces the REER and the investment grade yield with the real house price and the yield on 30-year fixed-rate mortgages.
} 
- $\quad$ By contrast, a shock to short-term interest rates leads to a persistent decline in residential investment, while the responses of nonresidential fixed investment and private consumption are minimal.

- Residential investment is highly sensitive to long-term interest rates (in this case the rate on 30-year fixed-rate mortgages). The responses of nonresidential investment and consumption are important but the impact takes longer to manifest itself.

- Innovations to equity returns are also associated with increases in all components of demand. The response of residential investment is smaller than for other financial conditions, while the response of consumption is comparable to those for lending standards and long-term interest rates. Nonresidential investment responds more quickly to equity returns than to long-term interest rates, but the impact is also less persistent.

\section{F. Can the FCI See Into the Future?}

The strong coincident movement between the FCI and economic activity implies that the former contains a substantial amount of leading information, as it is comprised of movements occurring over a span of two years prior to the period under question. Figure 11 therefore shows the FCI extending through to the end of 2009, at which point it only refers to shocks that occurred in last quarter of 2007 and first quarter of 2008. The impact of shocks in those two quarters would pull the FCI from 0.4 in the first quarter of 2008 to -0.7 by the end of 2009, in the absence of other disturbances. This underlines the importance of keeping in mind the transmission lags from financial markets to real activity.

As a further test of the ability of the FCI to lead growth, we constructed a "leading FCI", which only measures the impact of shocks that occurred from 3 through 8 quarters prior to the one under analysis. Any information contained in this index would be available to forecasters with at least six months of lead time. The index, shown in Figure 15 , does almost as good a job as the standard FCI in predicting economic activity_indeed, the correlations with $y / y$ and $q / q$ growth remain at 0.67 and 0.46 (Table 3). The respective correlations of the Conference Board's U.S. leading index with growth two quarters ahead are 0.52 and 0.27. The leading FCI would have given forecasters advance notice of the 2001 recession and an accurate indication of the timing of the recovery. It also would have given a significant early warning as to the timing and magnitude of the current downturn.

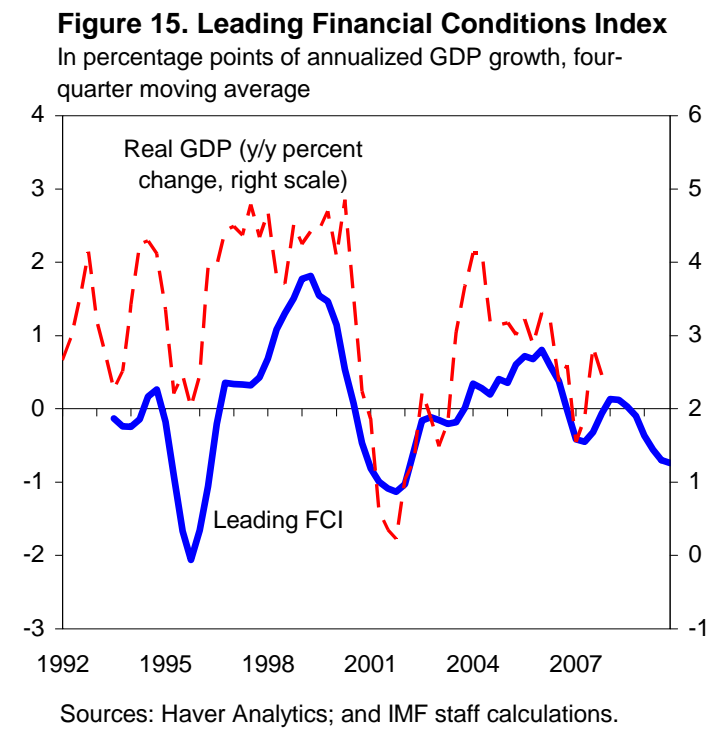




\section{Conclusions}

This paper has explained the construction of an FCI for the United States that accounts for the role of credit availability—shifts in the supply of credit—in driving economic fluctuations. The VAR framework used here allows for dynamic interaction between financial variables and growth, more realistically capturing the nature of macro-financial linkages than other estimation methodologies. The FCI does not represent a set of deep structural parameters, but does provide quantitative estimates of the typical recent effects on economic activity of the main financial transmission channels. Overall, this FCI tracks growth quite closely and serves as an accurate leading indicator of the business cycle. Lending standards, interest rates on corporate debt, equity returns, and the real exchange rate all have significant effects on growth.

Lending standards as reported by the Federal Reserve's Senior Loan Officer Opinion Survey on Bank Lending Practices are a valid proxy for credit availability. They appear to capture credit supply effects not only at commercial banks but throughout the economy. We find that a net tightening in commercial and industrial loan standards of 20 percentage points reduces GDP by $3 / 4$ percent over 1 year and 11/4 percent over 2 years, in line with other estimates using this variable (Lown and Morgan 2002, 2006; Bayoumi and Melander, 2008). In total, credit availability accounts for over 20 percent of the typical contribution of financial factors to growth. Much of the impact of lending standards can be traced through standards' significant influence on other financial variables, as a tightening of standards is typically associated with a sharp decline in equity returns and a widening of spreads on risky corporate debt. Lending standards retain their importance for growth even when accounting for the forward-looking information contained in other financial markets. This is strong evidence of a causal relationship between credit availability and economic activity, and discredits the idea that lending standards merely tighten as a precaution when an economic slowdown is foreseen.

A large proportion of the effects of monetary policy on growth since 1990 appear to have worked through their impact on the availability of credit, which advocates for the existence of a credit channel of monetary policy. The sensitivity of credit availability to monetary policy calls for monetary policymakers to pay attention to the effects of their instruments on economy-wide credit conditions. This holds true whether the central bank intends to stimulate or cool down the economy. The FCI's dynamic weights also highlight the importance of lagged transmission effects in determining whether a monetary policy setting is accommodative or restrictive. Avenues for further research include extending this approach to other countries, and examining the robustness of the current findings to the use of Bayesian estimation or structural VAR methods. 


\section{References}

Ashcraft, A., and M. Campello, 2007, "Firm Balance Sheets and Monetary Policy Transmission” Journal of Monetary Economics, Vol. 54 (September), pp. 1515-28.

Batini, N., and K. Turnbull, 2002, “A Dynamic Monetary Conditions Index for the UK,” Journal of Policy Modelling, Vol. 24 (June), pp. 257-81.

Bayoumi, T., and O. Melander, 2008, “Credit Matters: Empirical Evidence on U.S. MacroFinancial Linkages,” forthcoming IMF Working Paper.

Bernanke, B., and A. Blinder, 1988, “Credit, Money, and Aggregate Demand,” American Economic Review, Vol. 78 (May: Papers and Proceedings), pp. 435-9.

_, 1992 , “The Federal Funds Rate and the Channels of Monetary Transmission,” American Economic Review, Vol. 82 (September), pp. 901-921.

, Gertler, M., 1995, “Inside the Black Box: The Credit Channel of Monetary Policy Transmission,” Journal of Economic Perspectives, Vol. 9 (Fall), pp. 27-48.

— Gilchrist, S., 1999, “The Financial Accelerator in a Quantitative Business Cycle Framework,” in J. Taylor \& M. Woodford (eds.), Handbook of Macroeconomics, Vol. 1C, pp. 1341-1393.

— Mihov, I., 1998, “Measuring Monetary Policy,” Quarterly Journal of Economics, Vol. 113 (August), pp. 869-902.

—_ Boivin, J., and P. Eliasz, 2005, "Measuring the Effects of Monetary Policy: A FactorAugmented Vector Autoregressive (FAVAR) Approach,” Quarterly Journal of Economics, Vol. 120 (February), pp. 387-422.

Boschen, J., and L. Mills, 1991, "The Effects of Countercyclical Policy on Money and Interest Rates: An Evaluation of Evidence from FOMC Documents,” Federal Reserve Bank of Philadelphia Working Paper 91-20.

Christiano, L., M. Eichenbaum, and C. Evans, 1996, “The Effects of Monetary Policy Shocks: Evidence from the Flow of Funds," The Review of Economics and Statistics, Vol. 78 (February), pp. 16-34.

Dudley, W. and J. Hatzius, 2000, “The Goldman Sachs Financial Conditions Index: The Right Tool for a New Monetary Policy Regime,” Goldman Sachs Global Economics Paper No. 44.

Eika, K., N. Ericsson, and R. Nymoen, 1996, "Hazards in Implementing a Monetary Conditions Index,” Oxford Bulletin of Economics and Statistics, Vol. 58 (November), pp. 765-90.

Emery, K., 1996, “The Information Content of the Paper-Bill Spread,” Journal of Economics and Business, Vol. 48 (February), pp. 1-10.

English, W., K. Tsatsaronis, and E. Zoli, 2005, “Assessing the Predictive Power of Measures of Financial Conditions for Macroeconomic Variables,” BIS Papers: Number 22.

Friedman, M., and A. Schwartz, 1963, A Monetary History of the United States, 1867-1960 (Princeton, NJ: Princeton University). 
Gambacorta, L., and P. Mistrulli, 2004, “Does Bank Capital Affect Lending Behavior?” Journal of Financial Intermediation, Vol. 13 (October), pp. 436-57.

Gauthier, C., C. Graham, and Y. Liu, 2004, “Financial Conditions Indexes for Canada,” Bank of Canada Working Paper 2004-22.

Gertler, M., and S. Gilchrist, 1994, "Monetary Policy, Business Cycles, and the Behavior of Small Manufacturing Firms,” Quarterly Journal of Economics, Vol. 109 (May), pp. 309-40.

— Lown C., 1999, “The Information in the High Yield Bond Spread for the Business Cycle: Evidence and Some Implications,” Oxford Review of Economic Policy, Vol. 15 (Autumn), pp. 132-50.

Goodhart, C., and B. Hofmann, 2001, “Asset Prices, Financial Conditions, and the Transmission of Monetary Policy,” Paper presented at conference on Asset Prices, Exchange Rates, and Monetary Policy. Available online at: http://www.frbsf.org/economics/conferences/0103/index.html

_ Economic Society Annual Conference.

Greenlaw, D., J. Hatzius, A. Kashyap, and H. Shin, 2008, "Leveraged Losses: Lessons from the Mortgage Market Meltdown,” Paper presented at U.S. Monetary Policy Forum Conference. Available online at: http://www.chicagogsb.edu/usmpf/docs/usmpf2008confdraft.pdf

Kashyap, A., and J. Stein, 2000, "What Do a Million Observations on Banks Say About the Transmission of Monetary Policy?” American Economic Review, Vol. 90 (June), pp. 407-428.

Lown, C., D. Morgan, and S. Rohatgi, 2000, “Listening to Loan Officers: The Impact of Commercial Credit Standards on Lending and Output,” Federal Reserve Bank of New York Economic Policy Review (July), pp. 1-16.

_ 2002, “Credit Effects in the Monetary Mechanism,” Federal Reserve Bank of New York Economic Policy Review (May), pp. 217-235.

— 2006 , “The Credit Cycle and the Business Cycle: New Findings Using the Loan Officer Opinion Survey,” Journal of Money, Credit, and Banking, Vol. 38 (September), pp. 1575-97.

Macroeconomic Advisers, 1998, “From the U.S. Economic Outlook,” Technical Notes: September 5.

Mayes, D. and M. Virén, 2001, “Financial Conditions Indexes,” Bank of Finland Discussion Paper No. 2001-17.

Mody, A., and M. Taylor, 2003, “The High-Yield Spread as a Predictor of Real Economic Activity: Evidence of a Financial Accelerator for the United States,” IMF Staff Papers, Vol. 50 (No. 3), pp. 373-402.

Pesaran, H., and Y. Shin, 1998, “Generalized Impulse Response Analysis in Linear Multivariate Models,” Economics Letters, Vol. 58 (January), pp. 17-29. 
Romer, C., and D. Romer, 1989, "Does Monetary Policy Matter? A New Test in the Spirit of Friedman and Schwartz,” in O. Blanchard and S. Fischer (eds.), NBER Macroeconomics Annual (Cambridge, MA: MIT), pp. 121-70.

Sims, C., 1980, “Macroeconomics and Reality,” Econometrica, Vol. 48 (January), pp. 1-48.

— 1992 , "Interpreting the Macroeconomic Time Series Facts: The Effects of Monetary Policy,” European Economic Review, Vol. 36 (June), pp. 975-1011.

Stiglitz, J., and A. Weiss, 1981, "Credit Rationing in Markets with Imperfect Information,” American Economic Review, Vol. 71 (June), pp. 393-410.

Stock, J., and M. Watson, 1989, “New Indexes of Coincident and Leading Economic Indicators," in O. Blanchard and S. Fischer (eds.), NBER Macroeconomics Annual (Cambridge, MA: MIT), pp. 352-94.

_ Economic Literature, Vol. 91 (September), pp. 788-829.

Strongin, S., 1995, “The Identification of Monetary Policy Disturbances: Explaining the Liquidity Puzzle,” Journal of Monetary Economics, Vol. 35 (August), pp. 463-97.

Taylor, J., and J. Williams, 2008, “A Black Swan in the Money Market,” Federal Reserve Bank of San Francisco Working Paper 2008-04.

Van den Heuvel, S., 2002, “Does Bank Capital Matter for Monetary Transmission?” Federal Reserve Bank of New York Economic Policy Review (May), pp. 259-65. 